Article

\title{
Synthesis of Novel Methyl 7-[(Hetero)arylamino]thieno[2,3-b] pyrazine-6-carboxylates and Antitumor Activity Evaluation: Effects in Human Tumor Cells Growth, Cell Cycle Analysis, Apoptosis and Toxicity in Non-Tumor Cells
}

\author{
Juliana M. Rodrigues ${ }^{1}$, Ricardo C. Calhelha ${ }^{2} \mathbb{D}$, António Nogueira ${ }^{2} \mathbb{D}$, Isabel C. F. R. Ferreira ${ }^{2} \mathbb{D}$, Lillian Barros $^{2} \mathbb{D}$ \\ and Maria-João R. P. Queiroz ${ }^{1, *(\mathbb{D})}$ \\ check for \\ updates \\ 1 Centro de Química, Universidade do Minho (CQUM), Campus de Gualtar, 4710-057 Braga, Portugal; \\ id7018@alunos.uminho.pt \\ 2 Centro de Investigação de Montanha (CIMO), Instituto Politécnico de Bragança, Campus de Santa Apolónia, \\ 5300-253 Bragança, Portugal; calhelha@ipb.pt (R.C.C.); ajmnogueira@ipb.pt (A.N.); \\ iferreira@ipb.pt (I.C.F.R.F.); Lillian@ipb.pt (L.B.) \\ * Correspondence: mjrpq@quimica.uminho.pt
}

Citation: Rodrigues, J.M.; Calhelha, R.C.; Nogueira, A.; Ferreira, I.C.F.R.; Barros, L.; Queiroz, M.-J.R.P. Synthesis of Novel Methyl 7-[(Hetero)arylamino]thieno[2,3b]pyrazine-6-carboxylates and Antitumor Activity Evaluation: Effects in Human Tumor Cells Growth, Cell Cycle Analysis, Apoptosis and Toxicity in Non-Tumor Cells. Molecules 2021, 26, 4823. https://doi.org/10.3390/ molecules 26164823

Academic Editors:

Margherita Brindisi and

Jean-Marc Sabatier

Received: 4 July 2021

Accepted: 5 August 2021

Published: 10 August 2021

Publisher's Note: MDPI stays neutral with regard to jurisdictional claims in published maps and institutional affiliations.

Copyright: (c) 2021 by the authors. Licensee MDPI, Basel, Switzerland. This article is an open access article distributed under the terms and conditions of the Creative Commons Attribution (CC BY) license (https:/ / creativecommons.org/licenses/by/ $4.0 /)$.

\begin{abstract}
Several novel methyl 7-[(hetero)arylamino]thieno[2,3-b]pyrazine-6-carboxylates were synthesized by Pd-catalyzed C-N Buchwald-Hartwig cross-coupling of either methyl 7-aminothieno[3,2- $b$ ] pyrazine-6-carboxylate with (hetero)arylhalides or 7-bromothieno[2,3-b]pyrazine-6-carboxylate with (hetero)arylamines in good-to-excellent yields (50\% quantitative yield), using different reaction conditions, namely ligands and solvents, due to the different electronic character of the substrates. The antitumoral potential of these compounds was evaluated in four human tumor cell lines: gastric adenocarcinoma (AGS), colorectal adenocarcinoma (CaCo-2), breast carcinoma (MCF7), and non-small-cell lung carcinoma (NCI-H460) using the SRB assay, and it was possible to establish some structure-activity relationships. Furthermore, they did not show relevant toxicity against a non-tumor cell line culture from the African green monkey kidney (Vero). The most promising compounds $\left(\mathrm{GI}_{50} \leq 11 \mu \mathrm{M}\right)$, showed some selectivity either against AGS or CaCo-2 cell lines without toxicity at their $\mathrm{GI}_{50}$ values. The effects of the methoxylated compounds $\mathbf{2} \mathbf{b}\left(2-\mathrm{OMeC}_{6} \mathrm{H}_{4}\right), \mathbf{2} \mathbf{f}$ and $\mathbf{2 g}$ (3,4- or 3,5-diOMeC $\mathrm{H}_{3}$, respectively) on the cell cycle profile and induction of apoptosis were further studied in the AGS cell line. Nevertheless, even for the most active $\left(\mathrm{GI}_{50}=7.8 \mu \mathrm{M}\right)$ and selective compound ( $\mathbf{2 g}$ ) against this cell line, it was observed that a huge number of dead cells gave rise to an atypical distribution on the cell cycle profile and that these cells were not apoptotic, which points to a different mechanism of action for the AGS cell growth inhibition.
\end{abstract}

Keywords: C-N Buchwald-Hartwig coupling; thieno[2,3-b]pyrazines; antitumor activity; gastric adenocarcinoma; cell cycle; apoptosis

\section{Introduction}

The Pd-catalyzed amination of aryl halides has become a fundamental tool in the synthesis of di(hetero)arylamines over the past two decades [1-10]. As this type of compounds plays important roles in the development of pharmaceuticals, agrochemicals, and organic compounds for materials science, the scope of application of the C-N Buchwald-Hartwig cross-coupling was developed and improved, using different ligands, bases, and catalysts, which promoted general methodologies that find applications either in academic research or industry. The choice of the catalyst system is largely dependent on the geometric and electronic character of the substrates. The use of different bases allowed the development of stronger or milder conditions depending on the functional moieties in the substrates. Over the years, some generations of ligands were developed: the monodentate phosphines $\mathrm{PAr}_{3}$-type or $\mathrm{PR}_{3}$ that have often been employed; the bidentate phosphines including 
the most commonly used rac-BINAP and Xantphos; and the dialkylbiarylphosphines that due to their structural variability can be tuned to promote the desired reactivity or selectivity [11-13].

The thieno[2,3-b]pyrazine skeleton has been found in natural products such as urothion and its derivatives [14] and in biologically active synthetic compounds. Some derivatives have been described as selective inhibitors of serine/threonine kinase 4 associated with interleukine-1 receptor (IRAK 4) [15], as inhibitors of ubiquitin-specific protease 28 (USP 28) and/or USP 25 [16], and as serine/threonine kinase B-Raf inhibitors [17], all useful in the prevention or treatment of inflammation, cell proliferation, and immunerelated conditions and disease.

Our research group had already applied the C-N Buchwald-Hartwig cross-coupling to the synthesis of di(hetero)arylthieno[3,2-b]pyridines either functionalizing the pyridine $[18,19]$ or the thiophene ring [20], with some of them showing to be promising as potential antitumor compounds.

In this work, due to the biological relevance of the thieno[2,3-b]pyrazine moiety and of di(hetero)arilamines in general, a series of novel methyl 7-[(hetero)arylamino]thieno[2,3b]pyrazine-6-carboxylates were synthesized by Pd-catalyzed C-N Buchwald-Hartwig cross-coupling of either methyl 7-aminothieno[3,2-b]pyrazine-6-carboxylate with (hetero)arylhalides or 7-bromothieno[2,3-b]pyrazine-6-carboxylate with (hetero)arylamines in good-to-excellent yields, using different ligands and solvents, taking into account the electronic character of the coupling components. The antitumoral potential of the di(hetero)arylamines prepared against four human tumor cell lines and their toxicity using a non-tumor cell line were evaluated. The most promising compounds were submitted to cell cycle analysis and apoptosis induction studies in one of the cell lines studied.

\section{Results and Discussion}

\subsection{Synthesis of Methyl 7-[(Hetero)arylamino]thieno[2,3-b]pyrazine-6-carboxylates 2a-2o}

The coupling component methyl 7-aminothieno[2,3-b]pyrazine-2-carboxylate 1a was prepared following the procedure previously described by Peinador et al. [21]. Compound $1 \mathrm{a}$ was treated with $t$-butylnitrite $(t-\mathrm{BuONO})$ and $\mathrm{CuBr}_{2}$ in acetonitrile at room temperature, for $2 \mathrm{~h}$, to obtain the methyl 7-bromothieno[2,3-b]pyrazine-2-carboxylate $\mathbf{1 b}$ in $50 \%$ yield as another coupling component, following the reaction conditions earlier applied by us for the synthesis of a brominated thieno[3,2-b]pyridine [22] (Scheme 1).

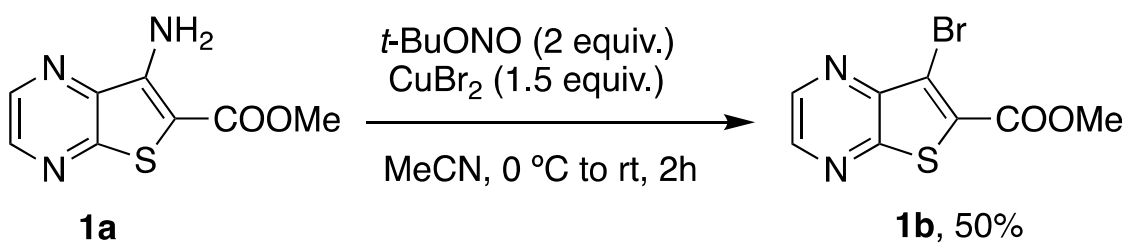

Scheme 1. Synthesis of methyl 7-bromothieno[2,3-b]pyrazine-2-carboxylate (1) $)$ from amine $\mathbf{1 a}$.

The coupling components $\mathbf{1 a}$ and $\mathbf{1 b}$ were reacted with (hetero)arylhalides or (hetero)arylamines, respectively. Based on our research group experience [18] and that of others [23] in C-N Buchwald-Hartwig couplings, deactivated amine 1a (bearing an EWG in the adjacent position) as coupling component, Xantphos as ligand, $\mathrm{Cs}_{2} \mathrm{CO}_{3}$ as the base, and 1,4-dioxane as solvent were used (Table 1 , reaction conditions A), while withthe activated bromo compound $\mathbf{1 b}$, for the cross-coupling reaction, rac-BINAP as the ligand, $\mathrm{Cs}_{2} \mathrm{CO}_{3}$ as the base, and toluene as solvent were used (Table 1, reaction conditions B). With these different conditions, taking into account the electronic character of the substrates, the corresponding di(hetero)arylamines $\mathbf{2 a - 2 o}$ were thus obtained in good-to-excellent yields. 
Table 1. Synthesis of di(hetero)arylamines 2a-2o by C-N Buchwald-Hartwig cross-coupling.

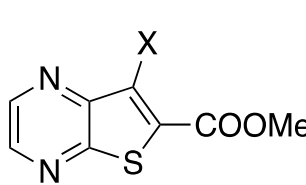

1a, $\mathrm{X}=\mathrm{NH}_{2}$

1b, $\mathrm{X}=\mathrm{Br}$
$X=\mathrm{NH}_{2}$, Halo(het)arylbenzene (1.1 equiv.)

$\mathrm{X}=\mathrm{Br}$, (het)Arylamine(1.1. equiv.) reaction conditions $\mathbf{A}$ or $\mathbf{B}$ under $\mathrm{Ar}$

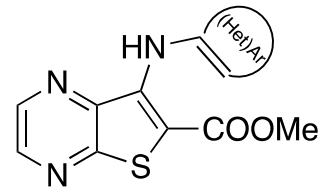

2a-0, $50 \%$ - quant. yield

\begin{tabular}{|c|c|c|c|c|c|}
\hline Entry & Precursor, Conditions & Compounds 2 & Entry & Precursor, Conditions & Compounds 2 \\
\hline 1 & 1a, A & $2 a, 5$ h, $50 \%$ & 9 & $1 b, B$ & $2 i, 2$ h, $82 \%$ \\
\hline 2 & 1b, B & $\begin{array}{l}\text { S } \\
2 b, 4 \text { h, } 65 \%\end{array}$ & 10 & $1 b, B$ & $2 \mathrm{j}, 2$ h, $89 \%$ \\
\hline 3 & $1 b, B$ & $2 \mathrm{~s}, 2 \mathrm{~h}, 80 \%$ & 11 & $1 b, B$ & $2 k, 2$ h, $70 \%$ \\
\hline 4 & $1 b, B$ & $2 d, 4 h, 75 \%$ & 12 & 1a, A & 2l, 2 h, 55\% \\
\hline 5 & $1 b, B$ & $2 e, 2$ h, quant & 13 & $1 b, B$ & $2 \mathrm{~m}, 6 \mathrm{~h}, 71^{\circ}$ \\
\hline 6 & $1 b, B$ & $2 f, 2$ h, $86 \%$ & 14 & 1a, A & 2n, $3.5 \mathrm{~h}$, quant \\
\hline
\end{tabular}


Table 1. Cont.

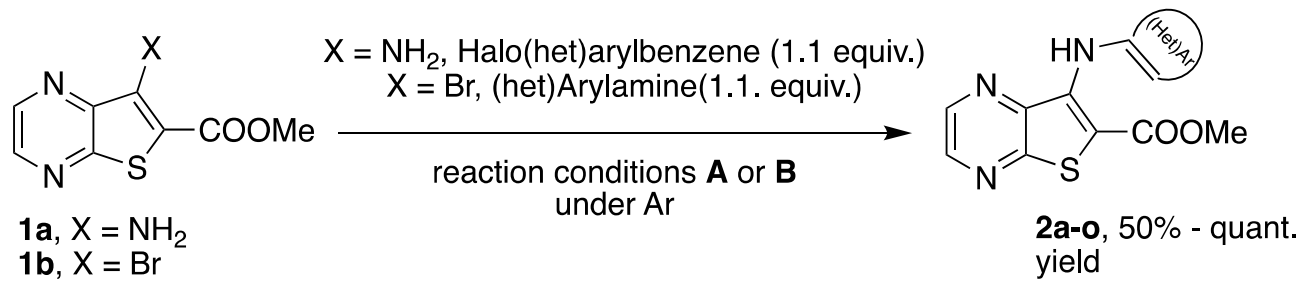

Entry Precursor, Conditions Compounds 2

Reaction conditions A: $\mathrm{Pd}(\mathrm{OAc})_{2}(10 \mathrm{~mol} \%$ ), Xantphos (12 mol. $\%), \mathrm{Cs}_{2} \mathrm{CO}_{3}$ (2.8 equiv.), 1,4-dioxane, $120^{\circ} \mathrm{C}, 3-5 \mathrm{~h}$. Reaction conditions B: $\mathrm{Pd}(\mathrm{OAc})_{2}(6 \mathrm{~mol} . \%)$, rac-BINAP $(8 \mathrm{~mol} . \%), \mathrm{Cs}_{2} \mathrm{CO}_{3}$ (2 equiv.), toluene, $100{ }^{\circ} \mathrm{C}, 2-6 \mathrm{~h}$.

From analysis of Table 1, it can be observed that the presence of either one methoxy group or a fluor atom in the anilines, in the coupling with $\mathbf{1 b}$, gave the corresponding di(hetero)arylamines $\mathbf{2} \mathbf{b}-\mathbf{2} \mathbf{d}$ and $\mathbf{2} \mathbf{i}-\mathbf{2} \mathbf{k}$, in good-to-high yields using reaction conditions B (entries 2-4 and 9-11). The di- and trimethoxylated anilines reacting with $\mathbf{1 b}$, in the same conditions, gave the corresponding di(hetero)arylamines $\mathbf{2 e - 2 h}$ in high-to-excellent yields due to the high activation of both substrates for the $\mathrm{C}-\mathrm{N}$ cross-coupling (entries 5-8). The reaction of amine 1a with the activated $p$-bromobenzonitrile gave compound $\mathbf{2 n}$ in quantitative yield using reaction conditions A (entry 14). Nevertheless, the couplings of the deactivated amine $1 \mathrm{a}$ using reaction conditions $\mathrm{A}$, with bromobenzene, 3-bromopyridine, and 2-bromonitrobenzene gave the corresponding products $\mathbf{2 a}, \mathbf{2 1}$, and $\mathbf{2 o}$ only in good yields (entries 1,12 , and 15 ). The formation of diheteroarylamine $\mathbf{2} \mathbf{m}$ from $\mathbf{1} \mathbf{b}$ and pyrrole in $71 \%$ yield (entry 13 ) was also notable.

\subsection{Cell Growth Inhibitory Effect of Compounds 2a-2o on AGS, CaCo-2, MCF7, NCI-H460 Cell} Lines and on a Non-Tumor Cell Line (Vero)

The antitumor potential of the di(hetero)arylamines $\mathbf{2 a - 2 o}$ was evaluated using the sulforhodamine B (SRB) assay [24,25] to establish some structure-activity relationships. Four human tumor cell lines (acquired from Leibniz-Institut DSMZ) were used: gastric adenocarcinoma (AGS), colorectal adenocarcinoma (CaCo-2), breast adenocarcinoma (MCF7), and non-small-cell lung cancer (NCI-H460), as well as a non-tumor cell line from African green monkey kidney (Vero) to evaluate the toxicity of the compounds. Ellipticine was used as a positive control, and the results are presented in $\mathrm{GI}_{50}$ values $(\mu \mathrm{M})$ (Table 2). 
Table 2. GI $_{50}$ concentrations of compounds $\mathbf{2 a - 2 o}$ and the positive control Ellipticine in four human tumor cell lines and in a non-tumor cell ${ }^{1}$.

\begin{tabular}{cccccc}
\hline \multicolumn{5}{c}{$\mathbf{G I}_{\mathbf{5 0}}(\boldsymbol{\mu M})^{\mathbf{1}}$} \\
\hline Compounds $\mathbf{2}$ & AGS & $\mathbf{C a C o - 2}$ & MCF-7 & NCI-H460 & Vero \\
\hline $\mathbf{2 a}$ & $95 \pm 9$ & $38 \pm 2$ & $97 \pm 2$ & $122 \pm 9$ & $120 \pm 6$ \\
$\mathbf{2 b}$ & $\mathbf{9 . 8} \pm \mathbf{0 . 2}$ & $36 \pm 2$ & $127 \pm 9$ & $45 \pm 1$ & $\mathbf{2 1 . 2 9} \pm \mathbf{0 . 0 3}$ \\
$\mathbf{2 c}$ & $98 \pm 3$ & $56 \pm 1$ & $160 \pm 6$ & $96 \pm 1$ & $94 \pm 3$ \\
$\mathbf{2 d}$ & $59 \pm 3$ & $60 \pm 2$ & $136 \pm 3$ & $52.8 \pm 0.3$ & $127 \pm 3$ \\
$\mathbf{2 e}$ & $34 \pm 2$ & $56 \pm 2$ & $140 \pm 7$ & $200 \pm 3$ & $138 \pm 8$ \\
$\mathbf{2 f}$ & $\mathbf{9 . 2} \pm \mathbf{0 . 2}$ & $\mathbf{8} \pm \mathbf{1}$ & $87 \pm 1$ & $41 \pm 3$ & $\mathbf{5 3} \pm \mathbf{3}$ \\
$\mathbf{2 g}$ & $\mathbf{7 . 8} \pm \mathbf{0 . 2}$ & $38 \pm 4$ & $182 \pm 5$ & $120 \pm 10$ & $\mathbf{1 4 4} \pm \mathbf{1 0}$ \\
$\mathbf{2 h}$ & $33 \pm 3$ & $\mathbf{9 . 2} \pm \mathbf{0 . 3}$ & $105.7 \pm 0.5$ & $77 \pm 6$ & $\mathbf{5 3} \pm \mathbf{5}$ \\
$\mathbf{2} \mathbf{i}$ & $48 \pm 4$ & $88.4 \pm 0.2$ & $128 \pm 5$ & $76 \pm 1$ & $117 \pm 10$ \\
$\mathbf{2 j}$ & $86 \pm 6$ & $142 \pm 11$ & $96 \pm 6$ & $69 \pm 7$ & $149 \pm 4$ \\
$\mathbf{2 k}$ & $118 \pm 2$ & $62 \pm 4$ & $160 \pm 7$ & $84 \pm 2$ & $149 \pm 7$ \\
$\mathbf{2 l}$ & $63.3 \pm 0.1$ & $45 \pm 3$ & $116 \pm 5$ & $122 \pm 11$ & $110 \pm 5$ \\
$\mathbf{2 m}$ & $88.6 \pm 0.1$ & $43.3 \pm 0.3$ & $128 \pm 2$ & $49 \pm 2$ & $140 \pm 12$ \\
$\mathbf{2 n}$ & $39 \pm 3$ & $\mathbf{1 0 . 9} \pm \mathbf{0 . 4}$ & $103 \pm 2$ & $105 \pm 8$ & $\mathbf{4 8} \pm \mathbf{4}$ \\
$\mathbf{2 0}$ & $55.0 \pm 0.3$ & $31.2 \pm 0.2$ & $103 \pm 3$ & $43 \pm 2$ & $92 \pm 8$ \\
Ellipticine & $0.9 \pm 0.1$ & $0.8 \pm 0.1$ & $1.020 \pm 0.004$ & $1.01 \pm 0.01$ & $0.6 \pm 0.1$ \\
(positive control) & & & & \\
\hline
\end{tabular}

${ }^{1} \mathrm{GI}_{50}$ values correspond to the compound concentration that causes $50 \%$ of cell growth inhibition. Results are expressed as mean values \pm standard deviation.

The results attained (Table 2) allow us to identify some promising antitumor compounds ( $\left.\mathrm{GI}_{50} \leq 11 \mu \mathrm{M}\right)$, namely against AGS and CaCo-2 cell lines. Compounds $\mathbf{2 f}, \mathbf{2} \mathbf{h}$, and $\mathbf{2 n}$ showed lower $\mathrm{GI}_{50}$ values against $\mathrm{CaCo}-2$ (8, 9.2, and $10.9 \mu \mathrm{M}$, respectively), $\mathbf{2 h}$ and $2 \mathrm{n}$ being selective for this cell line among the cell lines used. The presence of a cyano group in the para-position of the phenyl ring ( $2 n$ ) led to a decrease in the $\mathrm{GI}_{50}$ value $(10.9 \mu \mathrm{M})$ comparing with compound $\mathbf{2 a}$ with a non-substituted phenyl ring $(38 \mu \mathrm{M})$. It is noteworthy that for the $\mathrm{CaCo}-2$ cell line, the lowest $\mathrm{GI}_{50}$ values were obtained for di- and tri-methoxylated compounds $2 \mathbf{f}(8 \mu \mathrm{M})$ and $2 \mathbf{h}(9.2 \mu \mathrm{M})$, bearing simultaneous methoxy groups in the 3 and 4 positions on the phenyl ring relative to the amine, which seems to be an important feature for the inhibition of cell growth in this cell line.

Regarding the AGS cell line, the presence of methoxy groups is crucial for the cell growth inhibition, as observed for compounds $\mathbf{2 b}\left(2-\mathrm{OMeC}_{6} \mathrm{H}_{4}, 9.8 \mu \mathrm{M}\right), \mathbf{2 f}(3,4-$ $\left.\operatorname{diOMeC}_{6} \mathrm{H}_{3}, 9.2 \mu \mathrm{M}\right)$, and $\mathbf{2 g}\left(3,5-\mathrm{diOMeC}_{6} \mathrm{H}_{3}, 7.8 \mu \mathrm{M}\right)$. Compounds $\mathbf{2 b}$ and $\mathbf{2 g}$ were selective for this cell line, while compound $2 \mathrm{f}$ presented low $\mathrm{GI}_{50}$ values $(<10 \mu \mathrm{M})$ against both AGS and CaCo-2 cell lines (Table 2).

Notably, given the $\mathrm{GI}_{50}$ values presented for compound 2 in the AGS and CaCo-2 cell lines, they did not show relevant toxicity in the Vero non-tumor cell line presenting higher $\mathrm{GI}_{50}$ values. Despite the very low $\mathrm{GI}_{50}$ values $(\leq 1 \mu \mathrm{M})$ for the positive control Ellipticine in the human tumor cell lines tested, this is also toxic for the non-tumor line presenting a $\mathrm{GI}_{50}=0.6 \mu \mathrm{M}$ (Table 2).

Compound $2 \mathrm{~g}$ showed to be the most promising one due to its selectivity against the AGS cell line and the lowest $\mathrm{GI}_{50}$ value presented $(7.8 \mu \mathrm{M})$, together with the lower toxicity for the Vero cell line $\left(\mathrm{GI}_{50}=144 \mu \mathrm{M}\right)$.

With these results in hand, AGS cell cycle profile effects and induction of apoptosis studies for compounds $\mathbf{2 b}, \mathbf{2} \mathbf{f}$, and $\mathbf{2} \mathbf{g}$ were performed.

\subsection{Effects of Compounds $\mathbf{2} \mathbf{b}, \mathbf{2} \mathbf{f}$, and $\mathbf{2} \mathbf{g}$ on AGS Cell Cycle Profile}

AGS cell cycle analysis was carried out using propidium iodide (PI) staining and flow cytometry [26] for compounds $\mathbf{2} \mathbf{b}, \mathbf{2} \mathbf{f}$, and $\mathbf{2} \mathbf{g}$ at their $\mathrm{GI}_{50}$ concentrations (Table 2). This assay is based on the measurement of the DNA content in the PI-labeled nuclei. The results are presented in Figure 1. 


\section{Cell cycle analysis}

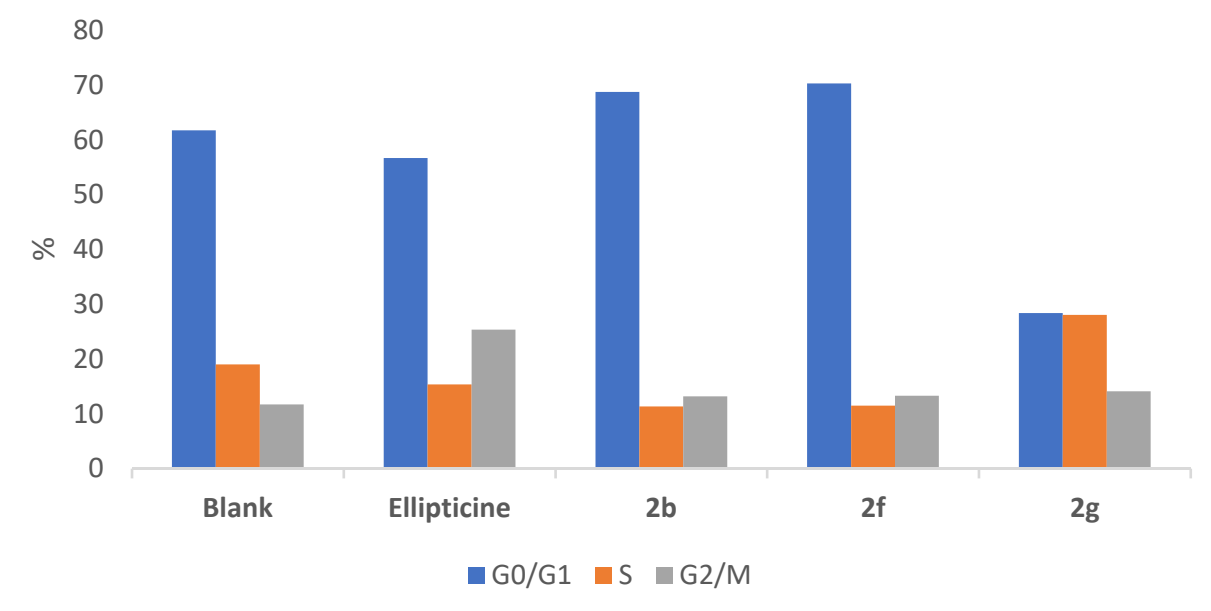

Figure 1. Effects of compounds $2 \mathbf{b}, \mathbf{2 f}$, and $2 \mathbf{g}$ on AGS cell cycle profile at their $\mathrm{GI}_{50}$ concentrations.

Compounds $\mathbf{2 b}$ and $\mathbf{2} \mathbf{f}$ caused cell cycle arrest in G0/G1 phases, although this result was not statistically significant (Qi2 test). On the other hand, for the G2/M phase, these compounds did not present any difference in the percentage of cells compared to the blank.

In Figure 2, histograms of the AGS cell cycle profile for blank and compound $\mathbf{2 f}$ are presented. Compound $\mathbf{2 b}$ presented a similar histogram to the one obtained for the blank, and compound $2 \mathrm{~g}$ caused a high percentage of cell death and an atypical distribution on cell cycle profile (results not shown).

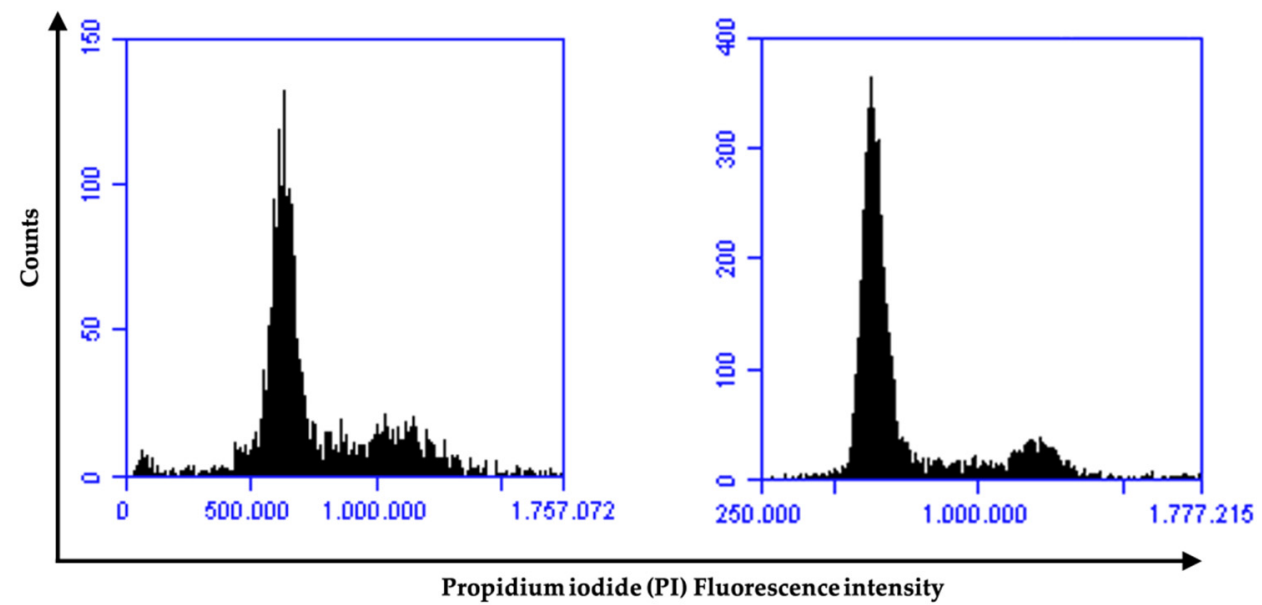

(a)

(b)

Figure 2. Cell cycle of blank (a) and compound $2 \mathbf{f}(\mathbf{b})$. Note that 250.000; 500.000; $1.000 .000 ; 1.757 .072$ and 1.777.215 correspond to 250,000; 500,000; 1,000,000; 1,757,072; 1,777,215.

\subsection{Effect of Compounds $\mathbf{2} \mathbf{b}, \mathbf{2} \mathbf{f}$, and $\mathbf{2} \mathbf{g}$ on Induction of Apoptosis in AGS Cell Line}

Apoptosis induction was performed using the Fluorescein Isothiocyanate (FITC) Annexin V Apoptosis Kit (BD Biosciences, San Jose, CA, USA), and measured by flow cytometry for compounds $\mathbf{2 b}, \mathbf{2 f}$, and $\mathbf{2 g}$ (Figure 3). FITC Annexin V staining was used to determine the percentage of cells within a population that are actively undergoing apoptosis [27]. 


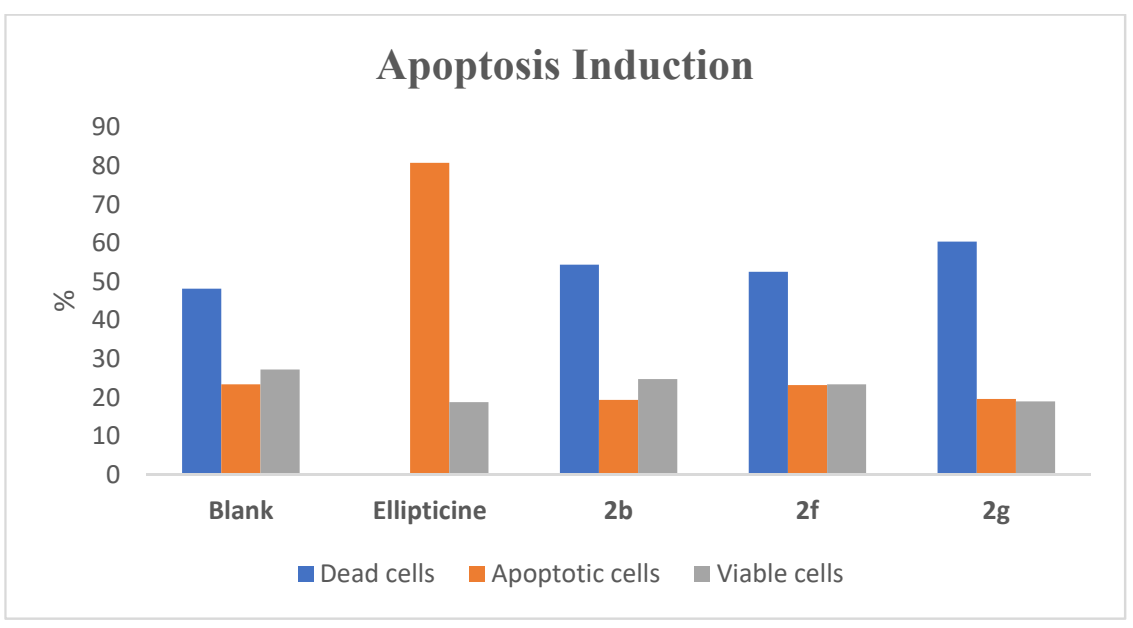

Figure 3. Induction of apoptotic process by compounds $\mathbf{2 b}, \mathbf{2} \mathbf{f}$, and $\mathbf{2} \mathbf{g}$ at their $\mathrm{GI}_{50}$ values in AGS cell line.

Regarding the apoptotic process, compound $2 \mathrm{~g}$ caused a large amount of cell death (Figures 3 and 4), which was in a similar range to what was observed in the cell cycle studies. In addition, compounds $\mathbf{2} \mathbf{b}$ and $\mathbf{2} \mathbf{f}$ also caused a moderated cell death compared to the blank (Figure 3).

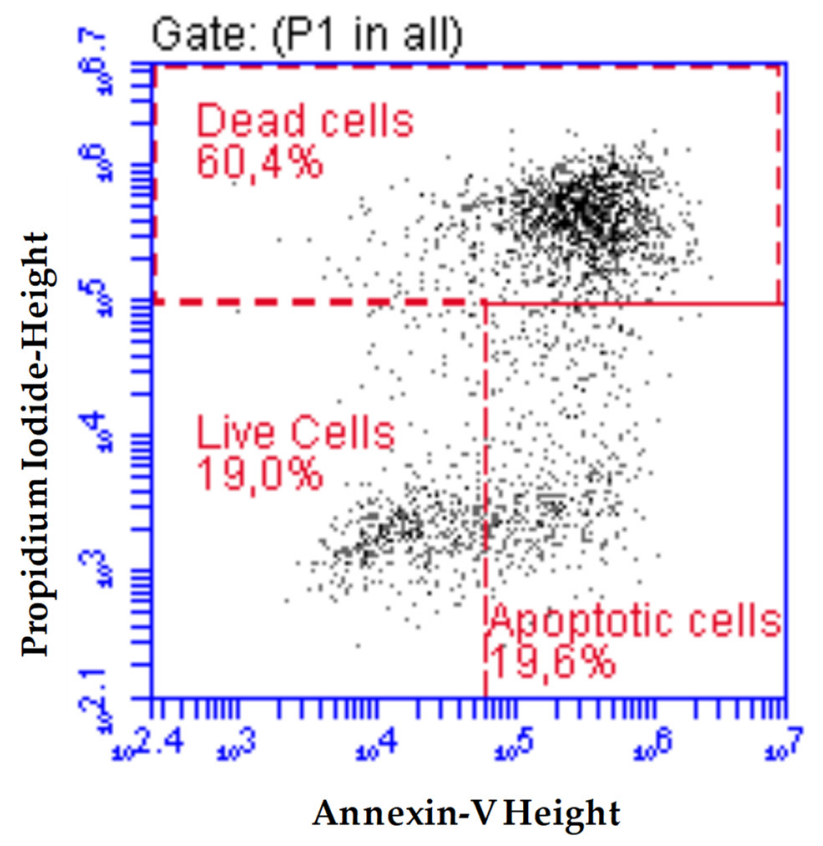

Figure 4. Compound $2 \mathrm{~g}$ apoptosis induction.

For the tested compounds ( $\mathbf{2} \mathbf{b}, \mathbf{2} \mathbf{f}$, and $\mathbf{2 g})$, a high number of cells in apoptosis was expected, due to the $\mathrm{GI}_{50}$ values obtained for the AGS cell line (Table 2). However, this was not verified, which led us to conclude that cytotoxicity against the AGS cell line involves mechanisms other than apoptosis.

\section{Materials and Methods}

\subsection{Chemistry}

Melting points $\left({ }^{\circ} \mathrm{C}\right)$ were determined in a SMP3 Stuart apparatus. ${ }^{1} \mathrm{H},{ }^{13} \mathrm{C}$, and ${ }^{19} \mathrm{~F}$ NMR spectra were recorded on a Bruker Advance III (Bruker, Bremen, Germany) at 400, 100.6 , and $376.48 \mathrm{MHz}$, respectively (see Supplementary Materials), using the signals of the non-deuterated solvents of $\mathrm{CHCl}_{3}(7.27 \mathrm{ppm})$ of the $\mathrm{CDCl}_{3}$ or of DMSO (2.49 ppm) of the DMSO- $d_{6}$, as internal reference relatively to TMS $(0 \mathrm{ppm})$. DEPT $\left(\theta=135^{\circ}\right)$ and 
bi-dimensional homo ${ }^{1} \mathrm{H}-1{ }^{1} \mathrm{H}(\mathrm{COSY})$ and heteronuclear correlations ${ }^{1} \mathrm{H}-{ }^{13} \mathrm{C}$ (HMQC and HMBC) were used to attribute some signals. HRMS were obtained at the external service of mass spectrometry of the University of Vigo using EI M ${ }^{+}$or ESI $[\mathrm{M}+\mathrm{H}]^{+}$. Reactions were followed by thin-layer chromatography (TLC). Dry flash column chromatography on silica gel $0.035-0.070 \mathrm{~mm}, 60 \mathrm{~A}$ and Celite ${ }^{\circledR} 545$ was used and this can be followed by column chromatography using solvent gradient to purify the compounds. Petroleum ether refers to the boiling range $40-60^{\circ} \mathrm{C}$. Ether refers to diethyl ether.

\subsubsection{Synthesis of Methyl 7-Bromothieno[2,3-b]pyrazine-6-carboxylate (1b)}

t-Butyl nitrite $(2.86 \mathrm{mmol}, 341.3 \mu \mathrm{L})$ was added to a solution of $\mathrm{CuBr}_{2}(2.15 \mathrm{mmol}$, $0.480 \mathrm{~g})$ in acetonitrile $(5 \mathrm{~mL})$ at $0{ }^{\circ} \mathrm{C}$, followed by addition of amine $1 \mathrm{a}(1.43 \mathrm{mmol}, 0.300 \mathrm{~g})$ in portions (three times, 5 min between each addition). The mixture was stirred for $2 \mathrm{~h}$ at room temperature. Then a saturated solution of $\mathrm{NH}_{4} \mathrm{Cl}(20 \mathrm{~mL})$ was added, and the aqueous phase was extracted with $\mathrm{CH}_{2} \mathrm{Cl}_{2}(3 \times 20 \mathrm{~mL})$. The combined organic phases were washed with $\mathrm{NH}_{4} \mathrm{Cl}_{\text {sat. }}(60 \mathrm{~mL})$, water $(60 \mathrm{~mL})$, and brine $(60 \mathrm{~mL})$, dried $\left(\mathrm{MgSO}_{4}\right)$ and filtered, and the solvent was removed under reduced pressure. The resulting residue was purified by column chromatography ( $30 \%$ ether $/ 70 \%$ petroleum ether) to give a solid that was crystalized from ether to give compound $1 \mathrm{~b}$ as a white solid $(0.196 \mathrm{~g}, 50 \%), \mathrm{m} . \mathrm{p} .161-163{ }^{\circ} \mathrm{C}$. ${ }^{1} \mathrm{H}$ NMR (400 MHz, DMSO- $\left.d_{6}\right): \delta=3.95(\mathrm{~s}, 3 \mathrm{H}, \mathrm{OMe}), 8.87(\mathrm{~d}, J=2.0 \mathrm{~Hz}, 1 \mathrm{H}, \mathrm{HetArH})$, $8.97(\mathrm{~d}, J=2.0 \mathrm{~Hz}, 1 \mathrm{H}, \mathrm{HetArH}) \mathrm{ppm} .{ }^{13} \mathrm{C}$ NMR $\left(100.6 \mathrm{MHz}, \mathrm{DMSO}-d_{6}\right): \delta=53.3(\mathrm{OMe})$, 115.0 (C), $131.0(\mathrm{C}), 145.0(\mathrm{CH}), 145.2(\mathrm{CH}), 146.0(\mathrm{C}), 153.5(\mathrm{C}), 160.5(\mathrm{C}=\mathrm{O}) \mathrm{ppm}$. HRMS (EI): $[\mathrm{M}]^{+}$calculated for $\mathrm{C}_{8} \mathrm{H}_{5}{ }^{79} \mathrm{BrN}_{2} \mathrm{O}_{2} \mathrm{~S}: 271.9255$, found: 271.9254 ; for $\mathrm{C}_{8} \mathrm{H}_{5}{ }^{81} \mathrm{BrN}_{2} \mathrm{O}_{2} \mathrm{~S}$ : 273.9235, found: 273.9243 .

\subsubsection{General Procedure for the Synthesis of Diarylamines Using Reaction Conditions A}

To a dried Schlenk tube with dry 1,4-dioxane (2-3 mL), compound 1a (1 equiv.), (hetero)arylhalide (1.1 equiv.), $\mathrm{Pd}(\mathrm{OAc})_{2}(10 \mathrm{~mol} . \%)$, Xantphos (12 mol.\%), and $\mathrm{Cs}_{2} \mathrm{CO}_{3}$ (2.8 equiv.) were added under argon. The reaction was stirred at $120^{\circ} \mathrm{C}$ for $2-5 \mathrm{~h}$. After cooling, the reaction mixture was passed through a pad of silica-gel covered with celite, using ether or AcOEt $(50 \mathrm{~mL})$. The removal of the solvent gave a solid that was washed with ether to isolate the product or the crude. The latter was submitted to column chromatography using a solvent gradient, increasing $10 \%$ each time, from 10/90 of ether/petroleum ether until the isolation of the product, unless stated.

\subsubsection{General Procedure for the Synthesis of Diarylamines Using Reaction Conditions B}

To a dried Schlenk tube with dry toluene ( $2-3 \mathrm{~mL}$ ), compound $\mathbf{1 b}$ (1 equiv.), (hetero)arylamine (1.1 equiv.), $\mathrm{Pd}(\mathrm{OAc})_{2}(6 \mathrm{~mol} . \%)$, rac-BINAP ( 8 mol. $\%$ ), and $\mathrm{Cs}_{2} \mathrm{CO}_{3}$ (2 equiv.) were added, under argon. The reaction was stirred at $100^{\circ} \mathrm{C}$ for $2-6 \mathrm{~h}$, and after cooling, the reaction mixture was passed through a pad of silica-gel covered with celite, using ether or AcOEt $(50 \mathrm{~mL})$. The removal of the solvent gave a solid that was washed with ether to isolate the product or the crude. The latter was submitted to column chromatography using a gradient of solvents, increasing $10 \%$ each time, from 10/90 of ether/petroleum ether until the isolation of the product, unless stated.

\section{Methyl 7-(Phenylamino)thieno[2,3-b]pyrazine-6-carboxylate (2a)}

From compound 1a $(0.380 \mathrm{mmol}, 80.0 \mathrm{mg})$, bromobenzene $(0.420 \mathrm{mmol}, 44.3 \mu \mathrm{L})$, following reaction conditions $\mathrm{A}$ and heating for $5 \mathrm{~h}$, compound $\mathbf{2 a}$ was obtained as a yellow solid after dry flash column chromatography using $40 \%$ ether/petroleum ether (55.0 mg, 50\%), m.p. ${ }^{154-156}{ }^{\circ} \mathrm{C} .{ }^{1} \mathrm{H}$ NMR $\left(400 \mathrm{MHz}, \mathrm{CDCl}_{3}\right): \delta=3.96(\mathrm{~s}, 3 \mathrm{H}, \mathrm{OMe})$, 7.10-7.13 (m, 3H, ArH), 7.27-7.31 (m, 2H, ArH), $8.51(\mathrm{~d}, J=2.0 \mathrm{~Hz}, 1 \mathrm{H}, \mathrm{HetArH}), 8.58(\mathrm{~d}$, $J=2.0 \mathrm{~Hz}, 1 \mathrm{H}, \mathrm{HetArH}), 8.87$ (broad s, $1 \mathrm{H}, \mathrm{NH}) \mathrm{ppm} .{ }^{13} \mathrm{C} \mathrm{NMR}\left(100.6 \mathrm{MHz}, \mathrm{CDCl}_{3}\right)$ : $\delta=52.3(\mathrm{OMe}), 107.0(\mathrm{C}), 121.5(2 \times \mathrm{CH}), 124.0(\mathrm{CH}), 129.0(2 \times \mathrm{CH}), 140.6(\mathrm{CH}), 141.0(\mathrm{C})$, $142.0(\mathrm{C}), 143.1(\mathrm{C}), 143.5(\mathrm{CH}), 155.5(\mathrm{C}), 165.2(\mathrm{C}=\mathrm{O})$. HRMS (ESI): $[\mathrm{M}+\mathrm{H}]^{+}$calculated for $\mathrm{C}_{14} \mathrm{H}_{12} \mathrm{~N}_{3} \mathrm{O}_{2} \mathrm{~S}$ : 286.0645, found: 286.0649 . 
Methyl 7-[(2-Methoxyphenyl)amino]thieno[2,3-b]pyrazine-6-carboxylate (2b)

From compound $\mathbf{1 b}(0.370 \mathrm{mmol}, 100.0 \mathrm{mg}), o$-anisidine $(0.400 \mathrm{mmol}, 45.4 \mu \mathrm{L})$, following reaction conditions $B$ and heating for $4 \mathrm{~h}$, compound $\mathbf{2 b}$ was obtained as a pale yellow solid $(75.0 \mathrm{mg}, 65 \%)$, m.p. $186-188^{\circ} \mathrm{C} .{ }^{1} \mathrm{H}$ NMR $\left(400 \mathrm{MHz}\right.$, DMSO- $\left.d_{6}\right): \delta=3.78$ (s, 3H, 2'-OMe), 3.87 (s, 3H, OMe), 6.76-6.82 (m, 1H, ArH), 7.01-7.03 (m, 2H, ArH), 7.06 (broad d, $J=7.6 \mathrm{~Hz}, 1 \mathrm{H}, \mathrm{ArH}), 8.64(\mathrm{~d}, J=2.4 \mathrm{~Hz}, 1 \mathrm{H}, \operatorname{HetArH}), 8.75(\mathrm{~d}, J=2.4 \mathrm{~Hz}$, $1 \mathrm{H}$, HetArH), 8.77 (broad s, $1 \mathrm{H}, \mathrm{NH}) \mathrm{ppm} .{ }^{13} \mathrm{C}$ NMR $\left(100.6 \mathrm{MHz}, \mathrm{DMSO}-d_{6}\right): \delta=52.4$ (OMe), $56.0\left(2^{\prime}-\mathrm{OMe}\right), 105.5(\mathrm{C}), 111.0(\mathrm{CH}), 120.0(\mathrm{CH}), 121.0(\mathrm{CH}), 123.5(\mathrm{CH}), 130.0(\mathrm{C})$, $141.4(\mathrm{CH}), 142.0(\mathrm{C}), 142.2(\mathrm{C}), 144.5(\mathrm{CH}), 150.2\left(2^{\prime}-\mathrm{C}\right), 154.0(\mathrm{C}), 164.2(\mathrm{C}=\mathrm{O}) \mathrm{ppm}$. HRMS (ESI): $[\mathrm{M}+\mathrm{H}]^{+}$calculated for $\mathrm{C}_{15} \mathrm{H}_{14} \mathrm{~N}_{3} \mathrm{O}_{3} \mathrm{~S}: 316.0750$, found: 316.0751 .

Methyl 7-[(3-Methoxyphenyl)amino]thieno[2,3-b]pyrazine-6-carboxylate (2c)

From compound $\mathbf{1 b}(0.370 \mathrm{mmol}, 100 \mathrm{mg}), \mathrm{m}$-anisidine $(0.400 \mathrm{mmol}, 45.4 \mu \mathrm{L})$, following reaction conditions $B$ and heating for $2 \mathrm{~h}$, compound $2 \mathrm{c}$ was obtained as a pale yellow solid $(92.0 \mathrm{mg}, 80 \%)$, m.p. $171-173{ }^{\circ} \mathrm{C} .{ }^{1} \mathrm{H}$ NMR $\left(400 \mathrm{MHz}, \mathrm{DMSO}-d_{6}\right): \delta=3.65(\mathrm{~s}, 3 \mathrm{H}$, 3'-OMe), 3.77 (s, 3H, OMe), 6.48 (apparent dd, $J=8.0$ and $2.0 \mathrm{~Hz}, 1 \mathrm{H}, \mathrm{ArH}$ ), 6.56 (broad d, $J=8.0 \mathrm{~Hz}, 1 \mathrm{H}, \mathrm{ArH}), 6.60$ (apparent $\mathrm{t}, J=2.0 \mathrm{~Hz}, 1 \mathrm{H}, 2^{\prime}-\mathrm{H}$ ), 7.05 (apparent $\mathrm{t}, J=8.0 \mathrm{~Hz}, 1 \mathrm{H}$, $\left.5^{\prime}-\mathrm{H}\right), 8.66(\mathrm{~d}, J=2.4 \mathrm{~Hz}, 1 \mathrm{H}$, HetArH), $8.72(\mathrm{~d}, J=2.4 \mathrm{~Hz}, 1 \mathrm{H}, \mathrm{HetArH}), 8.93$ (broad s, $1 \mathrm{H}$, $\mathrm{NH})$ ppm. ${ }^{13} \mathrm{C}$ NMR $\left(100.6 \mathrm{MHz}, \mathrm{DMSO}-d_{6}\right): \delta=52.4(\mathrm{OMe}), 55.0\left(3^{\prime}-\mathrm{OMe}\right), 105.4\left(2^{\prime}-\mathrm{CH}\right)$, $108.0(\mathrm{CH}), 109.1(\mathrm{C}), 112.0(\mathrm{CH}), 129.0\left(5^{\prime}-\mathrm{CH}\right), 141.0(\mathrm{C}), 142.0(\mathrm{CH}), 142.3(\mathrm{C}), 143.2(\mathrm{C})$, 144.5 (CH), 154.0 (C), $159.5\left(3^{\prime}-\mathrm{C}\right), 163.4(\mathrm{C}=\mathrm{O})$ ppm. HRMS (ESI): $[\mathrm{M}+\mathrm{H}]^{+}$calculated for $\mathrm{C}_{15} \mathrm{H}_{14} \mathrm{~N}_{3} \mathrm{O}_{3} \mathrm{~S}: 316.0750$, found: 316.0754 .

Methyl 7-[(4-Methoxyphenyl)amino]thieno[2,3-b]pyrazine-6-carboxylate (2d)

From compound $\mathbf{1 b}(0.370 \mathrm{mmol}, 100.0 \mathrm{mg}), p$-anisidine $(0.400 \mathrm{mmol}, 49.6 \mathrm{mg})$, following reaction conditions $B$ and heating for $4 \mathrm{~h}$, compound $\mathbf{2 d}$ was obtained as a pale yellow solid (87.0 mg, 75\%), m.p. $147-149^{\circ} \mathrm{C} .{ }^{1} \mathrm{H}$ NMR $\left(400 \mathrm{MHz}\right.$, DMSO- $\left.d_{6}\right): \delta=3.72$ $\left(\mathrm{s}, 3 \mathrm{H}, 4^{\prime}-\mathrm{OMe}\right), 3.83(\mathrm{~s}, 3 \mathrm{H}, \mathrm{OMe}), 6.81\left(\mathrm{~d}, J=8.8 \mathrm{~Hz}, 2 \mathrm{H}, 3^{\prime}\right.$ and $\left.5^{\prime}-\mathrm{H}\right), 7.05(\mathrm{~d}, J=8.8 \mathrm{~Hz}$, $2 \mathrm{H}, 2^{\prime}$ and $\left.6^{\prime}-\mathrm{H}\right), 8.60(\mathrm{~d}, J=2.4 \mathrm{~Hz}, 1 \mathrm{H}, \mathrm{HetArH}), 8.71(\mathrm{~d}, J=2.4 \mathrm{~Hz}, 1 \mathrm{H}, \mathrm{HetArH})$, $8.88($ broad s, $1 \mathrm{H}, \mathrm{NH}) \mathrm{ppm} .{ }^{13} \mathrm{C}$ NMR $\left(100.6 \mathrm{MHz}, \mathrm{DMSO}-d_{6}\right): \delta=52.2(\mathrm{OMe}), 55.2\left(4^{\prime}-\right.$ OMe), $105.0(\mathrm{C}), 114.0\left(3^{\prime}\right.$ and $\left.5^{\prime}-\mathrm{CH}\right), 123.0\left(2^{\prime}\right.$ and $\left.6^{\prime}-\mathrm{CH}\right), 134.4(\mathrm{C}), 141.3(\mathrm{CH}), 142.0(\mathrm{C})$, $143.0(\mathrm{C}), 144.3(\mathrm{CH}), 154.3(\mathrm{C}), 155.5\left(4^{\prime}-\mathrm{C}\right), 164.0(\mathrm{C}=\mathrm{O}) \mathrm{ppm}$. HRMS (ESI): $[\mathrm{M}+\mathrm{H}]^{+}$ calculated for $\mathrm{C}_{15} \mathrm{H}_{14} \mathrm{~N}_{3} \mathrm{O}_{3} \mathrm{~S}: 316.0750$, found: 316.0753 .

Methyl 7-[(2,4-Dimethoxyphenyl)amino]thieno[2,3-b]pyrazine-6-carboxylate (2e)

From compound $\mathbf{1 b}(0.220 \mathrm{mmol}, 60.0 \mathrm{mg})$, 2,4-dimethoxyaniline $(0.240 \mathrm{mmol}, 34.4 \mu \mathrm{L})$, following reaction conditions $B$ and heating for $2 \mathrm{~h}$, compound $2 \mathrm{e}$ was obtained as a red solid (76.0 mg, quantitative yield), m.p. $159-161{ }^{\circ} \mathrm{C} .{ }^{1} \mathrm{H} \mathrm{NMR}\left(400 \mathrm{MHz}, \mathrm{CDCl}_{3}\right): \delta=3.78(\mathrm{~s}$, $\left.3 \mathrm{H}, 2^{\prime}-\mathrm{OMe}\right), 3.83\left(\mathrm{~s}, 3 \mathrm{H}, 4^{\prime}-\mathrm{OMe}\right), 3.95(\mathrm{~s}, 3 \mathrm{H}, \mathrm{OMe}), 6.41\left(\mathrm{dd}, J=8.4\right.$ and $\left.2.4 \mathrm{~Hz}, 1 \mathrm{H}, 5^{\prime}-\mathrm{H}\right)$, $6.52\left(\mathrm{~d}, J=2.4 \mathrm{~Hz}, 1 \mathrm{H}, 3^{\prime}-\mathrm{H}\right), 7.05\left(\mathrm{~d}, J=8.4 \mathrm{~Hz}, 1 \mathrm{H}, 6^{\prime}-\mathrm{H}\right), 8.46(\mathrm{~d}, J=2.4 \mathrm{~Hz}, 1 \mathrm{H}, \mathrm{HetArH})$, $8.53(\mathrm{~d}, J=2.4 \mathrm{~Hz}, 1 \mathrm{H}, \mathrm{HetArH}), 8.79$ (broad s, $1 \mathrm{H}, \mathrm{NH}) \mathrm{ppm} .{ }^{13} \mathrm{C} \mathrm{NMR}(100.6 \mathrm{MHz}$, $\left.\mathrm{CDCl}_{3}\right): \delta=52.1(\mathrm{OMe}), 55.5\left(4^{\prime}-\mathrm{OMe}\right), 55.6\left(2^{\prime}-\mathrm{OMe}\right), 99.0\left(3^{\prime}-\mathrm{CH}\right), 103.3\left(5^{\prime}-\mathrm{CH}\right), 103.5(\mathrm{C})$, $123.0(\mathrm{C}), 124.0\left(6^{\prime}-\mathrm{CH}\right), 140.4(\mathrm{CH}), 142.2(\mathrm{C}), 143.3(\mathrm{CH}), 144.2(\mathrm{C}), 153.0\left(2^{\prime}-\mathrm{C}\right), 155.5(\mathrm{C})$, 157.4 (4'-C), $165.4(\mathrm{C}=\mathrm{O}) \mathrm{ppm}$. HRMS (ESI): $[\mathrm{M}+\mathrm{H}]^{+}$calculated for $\mathrm{C}_{16} \mathrm{H}_{16} \mathrm{~N}_{3} \mathrm{O}_{4} \mathrm{~S}: 346.0856$, found: 346.0856 .

Methyl 7-[(3,4-Dimethoxyphenyl)amino]thieno[2,3-b]pyrazine-6-carboxylate (2f)

From compound $\mathbf{1 b}(0.220 \mathrm{mmol}, 60.0 \mathrm{mg})$, 3,4-dimethoxyaniline $(0.240 \mathrm{mmol}, 37.0 \mathrm{mg})$ following the reaction conditions $\mathrm{B}$ and heating for $2 \mathrm{~h}$, compound $2 \mathrm{f}$ was obtained as a red solid $(65.0 \mathrm{mg}, 86 \%)$, m.p. $167-169{ }^{\circ} \mathrm{C} .{ }^{1} \mathrm{H}$ NMR $\left(400 \mathrm{MHz}, \mathrm{CDCl}_{3}\right): \delta=3.79(\mathrm{~s}, 3 \mathrm{H}$, $\left.3^{\prime}-\mathrm{OMe}\right), 3.89$ (s, 3H, 4'-OMe), $3.96(\mathrm{~s}, 3 \mathrm{H}, \mathrm{OMe}), 6.68\left(\mathrm{dd}, J=8.8\right.$ and $\left.2.4 \mathrm{~Hz}, 1 \mathrm{H}, 6^{\prime}-\mathrm{H}\right)$, $6.74\left(\mathrm{~d}, J=2.4 \mathrm{~Hz}, 1 \mathrm{H}, 2^{\prime}-\mathrm{H}\right), 6.79\left(\mathrm{~d}, J=8.8 \mathrm{~Hz}, 1 \mathrm{H}, 5^{\prime}-\mathrm{H}\right), 8.49(\mathrm{~d}, J=2.0 \mathrm{~Hz}, 1 \mathrm{H}, \mathrm{Het} A r \mathrm{H})$, $8.56(\mathrm{~d}, J=2.0 \mathrm{~Hz}, 1 \mathrm{H}, \mathrm{Het} A r H), 8.92($ broad s, $1 \mathrm{H}, \mathrm{NH}) \mathrm{ppm} .{ }^{13} \mathrm{C} \mathrm{NMR}(100.6 \mathrm{MHz}$, $\left.\mathrm{CDCl}_{3}\right): \delta=52.2(\mathrm{OMe}), 55.9\left(3^{\prime}-\mathrm{OMe}\right), 56.1\left(4^{\prime}-\mathrm{OMe}\right), 105.0(\mathrm{C}), 107.4\left(2^{\prime}-\mathrm{CH}\right), 111.1\left(5^{\prime}-\mathrm{CH}\right)$, 
$114.4\left(6^{\prime}-\mathrm{CH}\right), 134.3(\mathrm{C}), 140.5(\mathrm{CH}), 142.0(\mathrm{C}), 143.4(\mathrm{CH}), 144.0(\mathrm{C}), 146.1\left(4^{\prime}-\mathrm{C}\right), 149.0\left(3^{\prime}-\mathrm{C}\right)$, $156.0(\mathrm{C}), 165.5(\mathrm{C}=\mathrm{O})$ ppm. HRMS (ESI): $[\mathrm{M}+\mathrm{H}]^{+}$calculated for $\mathrm{C}_{16} \mathrm{H}_{16} \mathrm{~N}_{3} \mathrm{O}_{4} \mathrm{~S}: 346.0856$, found: 346.0856 .

Methyl 7-[(3,5-Dimethoxyphenyl)amino]thieno[2,3-b]pyrazine-6-carboxylate (2g)

From compound $\mathbf{1 b}(0.200 \mathrm{mmol}, 55.0 \mathrm{mg})$, 3,5-dimethoxyaniline $(0.220 \mathrm{mmol}, 33.9 \mathrm{mg})$, following reaction conditions $B$ and heating for $2 \mathrm{~h}$, compound $\mathbf{2 g}$ was obtained as a yellow solid $(56.0 \mathrm{mg}, 80 \%)$, m.p. $196-198{ }^{\circ} \mathrm{C} .{ }^{1} \mathrm{H}$ NMR $\left(400 \mathrm{MHz}, \mathrm{CDCl}_{3}\right): \delta=3.74(\mathrm{~s}, 6 \mathrm{H}$, $3^{\prime}$ and $\left.5^{\prime}-\mathrm{OMe}\right), 3.96(\mathrm{~s}, 3 \mathrm{H}, \mathrm{OMe}), 6.22-6.26\left(\mathrm{~m}, 3 \mathrm{H}, 4^{\prime}, 2^{\prime}\right.$ and $\left.6^{\prime}-\mathrm{H}\right), 8.56-8.60(\mathrm{~m}, 2 \mathrm{H}$, HetArH), 8.78 (broad s, $1 \mathrm{H}, \mathrm{NH})$ ppm. ${ }^{13} \mathrm{C} \mathrm{NMR}\left(100.6 \mathrm{MHz}, \mathrm{CDCl}_{3}\right): \delta=52.4(\mathrm{OMe})$, $55.3\left(3^{\prime}\right.$ and $\left.5^{\prime}-\mathrm{OMe}\right), 96.0\left(4^{\prime}-\mathrm{CH}\right), 100.0\left(2^{\prime}\right.$ and $\left.6^{\prime}-\mathrm{CH}\right), 108.4(\mathrm{C}), 141.0(\mathrm{CH}), 142.1(\mathrm{C})$, $142.7(\mathrm{C}), 143.0(\mathrm{C}), 144.0(\mathrm{CH}), 155.4(\mathrm{C}), 161.0\left(3^{\prime}\right.$ and $\left.5^{\prime}-\mathrm{C}\right), 165.1(\mathrm{C}=\mathrm{O})$. HRMS (ESI): $[\mathrm{M}+\mathrm{H}]^{+}$calculated for $\mathrm{C}_{16} \mathrm{H}_{16} \mathrm{~N}_{3} \mathrm{O}_{4} \mathrm{~S}: 346.0856$, found: 346.0858 .

Methyl 7-[(3,4,5-Trimethoxyphenyl)amino]thieno[2,3-b]pyrazine-6-carboxylate (2h)

From compound $\mathbf{1 b}(0.220 \mathrm{mmol}, 60.0 \mathrm{mg})$, 3,4-dimethoxyaniline $(0.240 \mathrm{mmol}, 44.3 \mathrm{mg})$, following reaction conditions $B$ and heating for $2 \mathrm{~h}$, compound $2 \mathrm{~h}$ was obtained as a dark orange solid (85.0 mg, quantitative yield), m.p. $194-196{ }^{\circ} \mathrm{C} .{ }^{1} \mathrm{H}$ NMR $(400 \mathrm{MHz}$, DMSO- $\left.d_{6}\right): \delta=3.62\left(\mathrm{~s}, 3 \mathrm{H}, 4^{\prime}-\mathrm{OMe}\right), 3.63\left(\mathrm{~s}, 6 \mathrm{H}, 3^{\prime}\right.$ and $\left.5^{\prime}-\mathrm{OMe}\right), 3.85(\mathrm{~s}, 3 \mathrm{H}, \mathrm{OMe})$, $6.43\left(\mathrm{~s}, 2 \mathrm{H}, 2^{\prime}\right.$ and $\left.6^{\prime}-\mathrm{H}\right), 8.69(\mathrm{~d}, J=2.0 \mathrm{~Hz}, 1 \mathrm{H}, \mathrm{HetArH}), 8.75(\mathrm{~d}, J=2.0 \mathrm{~Hz}, 1 \mathrm{H}, \mathrm{HetArH})$, $8.93($ broad s, $1 \mathrm{H}, \mathrm{NH}) \mathrm{ppm} .{ }^{13} \mathrm{C} \mathrm{NMR}\left(100.6 \mathrm{MHz}, \mathrm{CDCl}_{3}\right): \delta=52.4(\mathrm{OMe}), 55.7\left(3^{\prime}\right.$ and 5'-OMe), $60.1\left(4^{\prime}-\mathrm{OMe}\right), 98.4\left(2^{\prime}\right.$ and $\left.6^{\prime}-\mathrm{CH}\right), 107.0(\mathrm{C}), 133.2\left(4^{\prime}-\mathrm{C}\right), 137.4(\mathrm{C}), 141.4(\mathrm{CH})$, 141.5 (C), $142.0(\mathrm{C}), 144.4(\mathrm{CH}), 153.0\left(3^{\prime}\right.$ and $\left.5^{\prime}-\mathrm{C}\right), 154.2(\mathrm{C}), 164.0(\mathrm{C}=\mathrm{O}) \mathrm{ppm}$. HRMS (ESI): $[\mathrm{M}+\mathrm{H}]^{+}$calculated for $\mathrm{C}_{17} \mathrm{H}_{18} \mathrm{~N}_{3} \mathrm{O}_{5} \mathrm{~S}: 376.0962$, found: 376.0964 .

Methyl 7-[(2-Fluorophenyl)amino]thieno[2,3-b]pyrazine-6-carboxylate (2i)

From compound $\mathbf{1 b}(0.240 \mathrm{mmol}, 65.0 \mathrm{mg})$, 2-fluoroaniline $(0.260 \mathrm{mmol}, 25.3 \mu \mathrm{L})$, following reaction conditions $B$ and heating for $2 \mathrm{~h}$, compound $2 \mathbf{i}$ was obtained as a pale yellow solid after dry flash column chromatography till 10\% ether/petroleum ether $(59.0 \mathrm{mg}$, $82 \%)$, m.p. $137-139{ }^{\circ} \mathrm{C} .{ }^{1} \mathrm{H}$ NMR $\left(400 \mathrm{MHz}, \mathrm{CDCl}_{3}\right): \delta=3.97(\mathrm{~s}, 3 \mathrm{H}, \mathrm{OMe}), 7.03-7.13(\mathrm{~m}$, $3 \mathrm{H}), 7.19$ (broad apparent $\left.\mathrm{t}, J=8.0 \mathrm{~Hz}, 1 \mathrm{H}, 5^{\prime}-\mathrm{H}\right), 8.49(\mathrm{~d}, J=2.0 \mathrm{~Hz}, 1 \mathrm{H}, \mathrm{Het} A r \mathrm{H}), 8.58$ $(\mathrm{d}, J=2.0 \mathrm{~Hz}, 1 \mathrm{H}, \mathrm{HetArH}), 8.81$ (broad s, $1 \mathrm{H}, \mathrm{NH}) \mathrm{ppm} .{ }^{13} \mathrm{C} \mathrm{NMR}\left(100.6 \mathrm{MHz}, \mathrm{CDCl}_{3}\right)$ : $\delta=52.3(\mathrm{OMe}), 106.5(\mathrm{C}), 115.5\left(\mathrm{~d}, J=20.0 \mathrm{~Hz}, 3^{\prime}-\mathrm{CH}\right), 123.6(\mathrm{~d}, J=4.0 \mathrm{~Hz}, \mathrm{CH}), 123.8(\mathrm{~d}$, $\left.J=1.0 \mathrm{~Hz}, 5^{\prime}-\mathrm{CH}\right), 124.7(\mathrm{~d}, J=7.0 \mathrm{~Hz}, \mathrm{CH}), 128.9\left(\mathrm{~d}, J=13.0 \mathrm{~Hz}, 1^{\prime}-\mathrm{C}\right), 141.0(\mathrm{CH}), 142.0(\mathrm{C})$, $143.0(\mathrm{C}), 144.0(\mathrm{CH}), 155.3(\mathrm{C}), 155.5(\mathrm{~d}, J=245.0 \mathrm{~Hz}, \mathrm{C}-\mathrm{F}), 165.2(\mathrm{C}=\mathrm{O}) \mathrm{ppm} .{ }^{19} \mathrm{~F}$ NMR (376.48 MHz, $\mathrm{CDCl}_{3}$ ): $\delta=-125.5$ (s). HRMS (ESI): $[\mathrm{M}+\mathrm{H}]^{+}$calculated for $\mathrm{C}_{14} \mathrm{H}_{11} \mathrm{FN}_{3} \mathrm{O}_{2} \mathrm{~S}$ : 304.0551, found: 304.0555 .

Methyl 7-[(3-Fluorophenyl)amino]thieno[2,3-b]pyrazine-6-carboxylate (2j)

From compound $\mathbf{1 b}(0.220 \mathrm{mmol}, 60.0 \mathrm{mg})$, 3-fluoroaniline $(0.240 \mathrm{mmol}, 23.2 \mu \mathrm{L})$, following reaction conditions $B$ and heating for $2 \mathrm{~h}$, compound $\mathbf{2} \mathbf{j}$ was obtained as a yellow solid (59.0 mg, 89\%), m.p. $170-172{ }^{\circ} \mathrm{C} .{ }^{1} \mathrm{H}$ NMR $\left(400 \mathrm{MHz}, \mathrm{CDCl}_{3}\right): \delta=3.97(\mathrm{~s}, 3 \mathrm{H}$, OMe), 6.76-6.82 (m, 2H, ArH), 6.85-6.89 (m, 1H, 6'-H), 7.20-7.25 (m, 1H, 5'-H), 8.56 $(\mathrm{d}, J=2.0 \mathrm{~Hz}, 1 \mathrm{H}, \mathrm{HetArH}), 8.61(\mathrm{~d}, J=2.0 \mathrm{~Hz}, 1 \mathrm{H}, \mathrm{HetArH}), 8.84$ (broad s, $1 \mathrm{H}, \mathrm{NH})$ ppm. ${ }^{13} \mathrm{C}$ NMR $\left(100.6 \mathrm{MHz}, \mathrm{CDCl}_{3}\right): \delta=52.4(\mathrm{OMe}), 108.2(\mathrm{~d}, J=25.0 \mathrm{~Hz}, \mathrm{CH}), 109.0(\mathrm{C})$, $110.1(\mathrm{~d}, J=22.0 \mathrm{~Hz}, \mathrm{CH}), 116.5\left(\mathrm{~d}, J=2.0 \mathrm{~Hz}, 6^{\prime}-\mathrm{CH}\right), 129.7\left(\mathrm{~d}, J=9.0 \mathrm{~Hz}, 5^{\prime}-\mathrm{CH}\right), 141.0(\mathrm{CH})$ 142.0 (C), $142.2(\mathrm{C}), 142.8\left(\mathrm{~d}, J=10.0 \mathrm{~Hz}, 1^{\prime}-\mathrm{C}\right), 144.0(\mathrm{CH}), 155.4(\mathrm{C}), 163.0(\mathrm{~d}, J=245.0 \mathrm{~Hz}$, C-F), $165.1(\mathrm{C}=\mathrm{O}) \mathrm{ppm} .{ }^{19} \mathrm{~F}$ NMR (376.48 $\left.\mathrm{MHZ}, \mathrm{CDCl}_{3}\right): \delta=-112.7$ (s). HRMS (ESI): $[\mathrm{M}+\mathrm{H}]^{+}$calculated for $\mathrm{C}_{14} \mathrm{H}_{11} \mathrm{FN}_{3} \mathrm{O}_{2} \mathrm{~S}: 304.0551$, found: 304.0555 .

Methyl 7-[(4-Fluorophenyl)amino]thieno[2,3-b]pyrazine-6-carboxylate (2k)

From compound $\mathbf{1 b}(0.400 \mathrm{mmol}, 110.0 \mathrm{mg})$, 4-fluoroaniline $(0.440 \mathrm{mmol}, 42.0 \mu \mathrm{L})$, following reaction conditions $\mathrm{B}$ and heating for $2 \mathrm{~h}$, compound $2 \mathbf{k}$ was obtained as an orange solid $(86.0 \mathrm{mg}, 70 \%)$, m.p. $171-173{ }^{\circ} \mathrm{C} .{ }^{1} \mathrm{H}$ NMR $\left(400 \mathrm{MHz}, \mathrm{DMSO}-d_{6}\right): \delta=3.83(\mathrm{~s}, 3 \mathrm{H}$, 
$\mathrm{OMe}), 7.02-7.07\left(\mathrm{~m}, 2 \mathrm{H}, 3^{\prime}\right.$ and $\left.5^{\prime}-\mathrm{H}\right), 7.08-7.12\left(\mathrm{~m}, 2 \mathrm{H}, 2^{\prime}\right.$ and $\left.6^{\prime}-\mathrm{H}\right), 8.64(\mathrm{~d}, J=2.4 \mathrm{~Hz}$, $1 \mathrm{H}$, HetArH) $8.74(\mathrm{~d}, J=2.4 \mathrm{~Hz}, 1 \mathrm{H}$, HetArH), 8.97 (broad s, $1 \mathrm{H}, \mathrm{NH}) \mathrm{ppm} .{ }^{13} \mathrm{C} \mathrm{NMR}$ $\left(100.6 \mathrm{MHz}, \mathrm{DMSO}-d_{6}\right): \delta=52.4(\mathrm{OMe}), 107.3(\mathrm{C}), 114.8\left(\mathrm{~d}, J=22.0 \mathrm{~Hz}, 3^{\prime}\right.$ and $\left.5^{\prime}-\mathrm{CH}\right)$, $122.2\left(\mathrm{~d}, J=9.0 \mathrm{~Hz}, 2^{\prime}\right.$ and $\left.6^{\prime}-\mathrm{CH}\right), 138.1(\mathrm{C}), 138.12(\mathrm{C}), 141.5(\mathrm{CH}), 142.0(\mathrm{C}), 144.4(\mathrm{CH})$, $154.2(\mathrm{C}), 158.1$ (d, $J=238.4 \mathrm{~Hz}, \mathrm{C}-\mathrm{F}), 163.5(\mathrm{C}=\mathrm{O})$ ppm. ${ }^{19} \mathrm{~F}$ NMR (376.48 MHz, DMSO- $\left.d_{6}\right)$ : -121.1 (s). HRMS (ESI): [M + H] $]^{+}$calculated for $\mathrm{C}_{14} \mathrm{H}_{11} \mathrm{FN}_{3} \mathrm{O}_{2} \mathrm{~S}: 304.0551$, found: 304.0556 .

Methyl 7-[(Pyridin-3-yl)amino]thieno[2,3-b]pyrazine-6-carboxylate (21)

From compound 1a $(0.380 \mathrm{mmol}, 80.0 \mathrm{mg})$, 3-bromopyridine $(0.420 \mathrm{mmol}, 40.5 \mu \mathrm{L})$, following reaction condition $\mathrm{A}$ and heating for $2 \mathrm{~h}$, compound $\mathbf{2 l}$ was obtained as an orange solid after dry flash column chromatography till $80 \%$ ethyl acetate/petroleum ether $(60.0 \mathrm{mg}, 55 \%)$, m.p. ${ }^{150-152}{ }^{\circ} \mathrm{C} .{ }^{1} \mathrm{H} \mathrm{NMR}\left(400 \mathrm{MHz}, \mathrm{CDCl}_{3}\right): \delta=3.98(\mathrm{~s}, 3 \mathrm{H}$, OMe), $7.23\left(\mathrm{dd}, J=8.4\right.$ and $\left.4.8 \mathrm{~Hz}, 1 \mathrm{H}, 5^{\prime}-\mathrm{H}\right), 7.42-7.45\left(\mathrm{~m}, 1 \mathrm{H}, 4^{\prime}-\mathrm{H}\right), 8.35(\mathrm{dd}, J=4.8$ and $\left.1.2 \mathrm{~Hz}, 1 \mathrm{H}, 6^{\prime}-\mathrm{H}\right), 8.46-8.47\left(\mathrm{~m}, 1 \mathrm{H}, 2^{\prime}-\mathrm{H}\right), 8.50(\mathrm{~d}, J=2.0 \mathrm{~Hz}, 1 \mathrm{H}, \mathrm{HetArH}), 8.60(\mathrm{~d}$, $J=2.0 \mathrm{~Hz}, 1 \mathrm{H}, \mathrm{HetArH}), 8.92$ (broad s, $1 \mathrm{H}, \mathrm{NH}) \mathrm{ppm} .{ }^{13} \mathrm{C} \mathrm{NMR}\left(100.6 \mathrm{MHz}, \mathrm{CDCl}_{3}\right)$ : $\left.\delta=52.4(\mathrm{OMe}), 108.0(\mathrm{C}), 123.0\left(5^{\prime}-\mathrm{CH}\right), 128.44^{\prime}-\mathrm{CH}\right), 137.3(\mathrm{C}), 141.0(\mathrm{CH}), 141.5(\mathrm{C})$, $142.2(\mathrm{C}), 143.6\left(2^{\prime}-\mathrm{CH}\right), 144.0(\mathrm{CH}), 145.0\left(6^{\prime}-\mathrm{CH}\right), 155.5(\mathrm{C}), 165.3(\mathrm{C}=\mathrm{O})$ ppm. HRMS (ESI): $[\mathrm{M}+\mathrm{H}]^{+}$calculated for $\mathrm{C}_{13} \mathrm{H}_{11} \mathrm{~N}_{4} \mathrm{O}_{2} \mathrm{~S}: 287.0597$, found: 287.0592 .

Methyl 7-(1H-pyrrol-1-yl)thieno[2,3-b]pyrazine-6-carboxylate (2m)

From compound $\mathbf{1 b}(0.380 \mathrm{mmol}, 80.0 \mathrm{mg}), 1 H$-pyrrol $(0.420 \mathrm{mmol}, 40.5 \mu \mathrm{L})$, following reaction conditions B and heating for $6 \mathrm{~h}$, compound $2 \mathrm{~m}$ was obtained as an pale yellow solid after dry flash column chromatography till 30\% ether/petroleum ether $(54.0 \mathrm{mg}$, 71\%), m.p. $166-168{ }^{\circ} \mathrm{C} .{ }^{1} \mathrm{H}$ NMR $\left(400 \mathrm{MHz} \mathrm{CDCl}_{3}\right): \delta=3.93$ (s, 3H, OMe), 6.45 (apparent $\mathrm{t}$, $J=2.0 \mathrm{~Hz}, 2 \mathrm{H}, 2 \times$ HetArH), 7.13 (apparent $\mathrm{t}, J=2.0 \mathrm{~Hz}, 2 \mathrm{H}, 2 \times$ HetArH), $8.70(\mathrm{~d}, J=2.0$ $\mathrm{Hz}, 1 \mathrm{H}, \mathrm{HetArH}), 8.79(\mathrm{~d}, J=2.0 \mathrm{~Hz}, 1 \mathrm{H}, \mathrm{HetArH}) \mathrm{ppm} .{ }^{13} \mathrm{C} \mathrm{NMR}\left(100.6 \mathrm{MHz}, \mathrm{CDCl}_{3}\right)$ : $\delta=53.0(\mathrm{OMe}), 110.0(2 \times \mathrm{CH}), 123.0(2 \times \mathrm{CH}), 126.0(\mathrm{C}), 136.0(\mathrm{C}), 143.3(\mathrm{CH}), 144.0(\mathrm{CH})$, $144.3(\mathrm{C}), 154.3(\mathrm{C}), 161.1(\mathrm{C}=\mathrm{O})$ ppm. HRMS (ESI): $[\mathrm{M}+\mathrm{H}]^{+}$calculated for $\mathrm{C}_{12} \mathrm{H}_{10} \mathrm{~N}_{3} \mathrm{O}_{2} \mathrm{~S}$ : 260.0488, found: 260.0486 .

Methyl 7-[(4-Cyanophenyl)amino]thieno[2,3-b]pyrazine-6-carboxylate (2n)

From compound 1a $(0.380 \mathrm{mmol}, 80.0 \mathrm{mg})$, 4-bromobenzonitrile $(0.400 \mathrm{mmol}, 76.5 \mathrm{mg})$, following reaction conditions $\mathrm{A}$ and heating $3.5 \mathrm{~h}$, compound $\mathbf{2 n}$ was obtained as a yellow solid (119 mg, quantitative yield), m.p. $214-216{ }^{\circ} \mathrm{C} .{ }^{1} \mathrm{H} \mathrm{NMR}\left(400 \mathrm{MHz}, \mathrm{CDCl}_{3}\right): \delta=3.99$ (s, 3H, OMe), $7.11\left(\mathrm{~d}, J=8.8 \mathrm{~Hz}, 2 \mathrm{H}, 2^{\prime}\right.$ and $\left.6^{\prime}-\mathrm{H}\right), 7.54\left(\mathrm{~d}, J=8.8 \mathrm{~Hz}, 2 \mathrm{H}, 3^{\prime}\right.$ and $\left.5^{\prime}-\mathrm{H}\right)$, $8.60(\mathrm{~d}, J=2.0 \mathrm{~Hz}, 1 \mathrm{H}, \operatorname{HetArH}), 8.66(\mathrm{~d}, J=2.0 \mathrm{~Hz}, 1 \mathrm{H}, \operatorname{HetArH}), 8.90($ broad s, $1 \mathrm{H}, \mathrm{NH})$ ppm. ${ }^{13} \mathrm{C} \mathrm{NMR}\left(100.6 \mathrm{MHz}, \mathrm{CDCl}_{3}\right): \delta=53.0$ (OMe), $105.3(\mathrm{C}), 112.0(\mathrm{C}), 119.3(\mathrm{C}), 120.0$ ( $2^{\prime}$ and $\left.6^{\prime}-\mathrm{CH}\right), 133.0\left(3^{\prime}\right.$ and $\left.5^{\prime}-\mathrm{CH}\right), 140.5(\mathrm{C}), 141.1(\mathrm{CH}), 142.0(\mathrm{C}), 144.0(\mathrm{CH}), 145.2(\mathrm{C})$, $155.3(\mathrm{C}), 165.0(\mathrm{C}=\mathrm{O})$ ppm. HRMS (ESI): $[\mathrm{M}+\mathrm{H}]^{+}$calculated for $\mathrm{C}_{15} \mathrm{H}_{11} \mathrm{~N}_{4} \mathrm{O}_{2} \mathrm{~S}: 311.0597$, found: 311.0598 .

Methyl 7-[(2-Nitrophenyl)amino]thieno[2,3-b]pyrazine-6-carboxylate (2o)

From compound 1a $(0.450 \mathrm{mmol}, 95.0 \mathrm{mg})$, 2-nitrobenzene (0.500 mmol, $101.0 \mathrm{mg})$, following reaction conditions $\mathrm{A}$ and heating $3 \mathrm{~h}$, compound $2 \mathrm{o}$ was obtained as a yellow solid after dry flash column chromatography till $100 \%$ ethyl acetate $(90.0 \mathrm{mg}, 60 \%)$, m.p. $225-227^{\circ} \mathrm{C} .{ }^{1} \mathrm{H} \mathrm{NMR}\left(400 \mathrm{MHz} \mathrm{CDCl}_{3}\right): \delta=4.01(\mathrm{~s}, 3 \mathrm{H}, \mathrm{OMe}), 6.96-7.04(\mathrm{~m}, 2 \mathrm{H}$, ArH), 7.35-7.40 (m, 1H, ArH), $8.20\left(\mathrm{dd}, J=8.0\right.$ and $\left.1.6 \mathrm{~Hz}, 1 \mathrm{H}, 3^{\prime}-\mathrm{H}\right), 8.61$ (d, $J=2.0 \mathrm{~Hz}$, $1 \mathrm{H}$, HetArH) $8.67(\mathrm{~d}, J=2.0 \mathrm{~Hz}, 1 \mathrm{H}, \operatorname{Het} \mathrm{ArH}), 10.65($ broad s, $1 \mathrm{H}, \mathrm{NH}) \mathrm{ppm} .{ }^{13} \mathrm{C}$ NMR $\left(100.6 \mathrm{MHz}_{\mathrm{CDCl}}\right): \delta=53.0(\mathrm{OMe}), 117.5(\mathrm{C}), 120.4(\mathrm{CH}), 121.0(\mathrm{CH}), 126.0\left(3^{\prime}-\mathrm{CH}\right)$, $134.0(\mathrm{CH}), 136.4(\mathrm{C}), 137.5(\mathrm{C}), 138.4(\mathrm{C}), 141.4(\mathrm{CH}), 142.5(\mathrm{C}), 144.0(\mathrm{CH}), 155.0(\mathrm{C})$, 163.4 $(\mathrm{C}=\mathrm{O})$. HRMS (ESI): $[\mathrm{M}+\mathrm{H}]^{+}$calculated for $\mathrm{C}_{14} \mathrm{H}_{11} \mathrm{~N}_{4} \mathrm{O}_{4} \mathrm{~S}: 331.0496$, found: 331.0496 . 


\subsection{In Vitro Antitumor Evaluation}

\subsubsection{Cell Growth Inhibition Assay (SRB Assay)}

The cell growth inhibition of compounds 2a-2o DMSO/water solutions $(3.9-250 \mu \mathrm{M})$ was evaluated against four human tumor cell lines (acquired from Leibniz-Institut DSMZ), namely: gastric adenocarcinoma (AGS), colorectal adenocarcinoma (CaCo-2), breast carcinoma (MCF7), and non-small-cell lung carcinoma (NCI-H460), as well as a non-tumor culture from African green monkey kidney (Vero). Each cell line was prepared in 96-well plates, at the required density $\left(1.0 \times 10^{4}\right.$ cells/well $)$ and incubated for $24 \mathrm{~h}$ to achieve cell attachment. The solutions of the compounds were applied and incubated for another $48 \mathrm{~h}$. $\mathrm{GI}_{50}$ values $(\mu \mathrm{M})$ corresponding to the compound concentration that inhibited $50 \%$ of cell growth were determined using the sulforhodamine B assay $[24,25]$. Two separate tests were carried out for each compound, in duplicate, with the effects expressed as mean values and standard deviation (SD). Ellipticine was used as a positive control.

\subsubsection{Flow Cytometric: Cell Cycle Analysis}

AGS cells were seeded in six-well plates $\left(4 \times 10^{5}\right.$ cells /well) and incubated with the compounds $\mathbf{2 b}, \mathbf{2 f}$, and $\mathbf{2 g}$, at their $\mathrm{GI}_{50}$ concentration for each sample, for $72 \mathrm{~h}$. Cell cycle analysis was performed using propidium iodide (PI) staining and flow cytometry. This assay is established on the measurement of the DNA content of nuclei labeled with PI. Following this, the cells were staining according to the protocol PI/RNASE Solution (Immunostep, Spain, Salamanca). The harvested cells corresponding to $2 \times 10^{5}$ to $1 \times 10^{6}$ cells, were centrifuged for $5 \mathrm{~min}$ at $300 \mathrm{~g}$, and the supernatant was removed. The cells were fixed and added to $200 \mu \mathrm{L}$ of $70 \%$ ethanol and left in the ethanol at $4{ }^{\circ} \mathrm{C}$ for $30 \mathrm{~min}$. Following this, the cells were washed once in $2 \mathrm{~mL}$ phosphate-buffered saline (PBS) and centrifuged for $5 \mathrm{~min}$ at $300 \mathrm{~g}$ and resuspended in $500 \mu \mathrm{L}$ of PI solution (PI/RNASE) and incubated in the dark, at room temperature, for $15 \mathrm{~min}$. Cell cycle phase distribution was evaluated using an Accuri C6 flow cytometer (BD Biosciences, San Jose, CA, USA). The DNA content of at least 20,000 cells was counted per sample, and the percentage of cells in different phases (G0/G1, S, and G2/M phases) of the cell cycle was evaluated using BD Accuri C6 software (BD Biosciences, San Jose, CA, USA) [26]. Ellipticine was used as a positive control at its $\mathrm{GI}_{50}$ concentration for AGS cell line.

\subsubsection{Flow Cytometric: Apoptosis Detection}

AGS cells were seeded in six-well plates $\left(4 \times 10^{5}\right.$ cells/well $)$ and incubated with compounds $\mathbf{2 b}$, $2 \mathbf{f}$, and $\mathbf{2 g}$ at their $\mathrm{GI}_{50}$ concentration for each sample, for $72 \mathrm{~h}$. Apoptosis detection was performed using the Fluorescein Isothiocyanate (FITC) Annexin V Apoptosis Kit (BD Biosciences, San Jose, CA, USA) and flow cytometry. FITC Annexin V staining is used to determine the percentage of cells within a population that are actively undergoing apoptosis. The cells were washed twice with PBS and resuspended cells in $1 \times$ Binding Buffer (10 mM HEPES/NaOH, pH 7.4, $\left.140 \mathrm{mM} \mathrm{NaCl}, 2.5 \mathrm{mM} \mathrm{CaCl}_{2}\right)$ at a concentration of $1 \times 10^{6}$ cells $/ \mathrm{mL}$. Following this, $100 \mu \mathrm{L}$ of the solution $\left(1 \times 10^{5}\right.$ cells $)$ was transferred to a $5 \mathrm{~mL}$ culture tube and $5 \mu \mathrm{L}$ of FITC Annexin V (BD Biosciences, San Jose, CA, USA) and $5 \mu \mathrm{L}$ of PI (BD Biosciences, San Jose, CA, USA) were added to each tube, and they were incubated in the dark, at room temperature, for $15 \mathrm{~min}$. Finally, $400 \mu \mathrm{L}$ of $1 \times$ Binding Buffer was added to each tube. Next, 30,000 cells were acquired using an Accuri C6 flow cytometer (BD Biosciences, San Jose, CA, USA), and the percentage of cell distribution was evaluated with Accuri C6 software (BD Biosciences, San Jose, CA, USA) [27]. Ellipticine was used as a positive control at its $\mathrm{GI}_{50}$ concentration for AGS cell line.

\subsubsection{Statistical Analysis}

Statistical analysis of data was performed using SPSS Statistics (version 23 for Windows; IBM Corp., Armonk, NY, USA). Statistical differences between groups were assessed by the chi-square test and differences with a $p<0.05$ were considered significant. 


\section{Conclusions}

A series of novel di(hetero)arylamines were synthesized by $\mathrm{C}-\mathrm{N}$ Buchwald-Hartwig cross-coupling of either aminated or brominated thieno[2,3-b]pyrazines with (hetero)arylhalides or (hetero)arylamines, respectively, in good-to-excellent yields, using different reaction conditions, taking into account the electronic character of the substrates. The antitumor potential of the compounds obtained was evaluated against four human tumor cell lines (AGS, CaCo-2, MCF7, and NCI-H460). Despite the variety of the compounds, the results showed that the most promising ones were the mono- or dimethoxylated, $\mathbf{2} \mathbf{b}\left(2-\mathrm{OMeC}_{6} \mathrm{H}_{4}\right)$, $2 \mathrm{f}\left(3,5-\mathrm{diOMeC}_{6} \mathrm{H}_{3}\right)$, and $\mathbf{2 g}\left(3,4-\mathrm{diOMeC}_{6} \mathrm{H}_{3}\right)$ which presented the lowest $\mathrm{GI}_{50}$ values and selectively inhibited the cell growth of the AGS and/or CaCo-2 cell lines among the human tumor cell lines tested. Moreover, compound $\mathbf{2 h}\left(3,4,5\right.$-triOMeC $\left.{ }_{6} \mathrm{H}_{2}\right)$ and $\mathbf{2 n}(4-$ $\left.\mathrm{CNC}_{6} \mathrm{H}_{4}\right)$ showed to be selective against $\mathrm{CaCo}-2$ cell line presenting $\mathrm{GI}_{50}=9.2$ and $10.9 \mu \mathrm{M}$, respectively. The toxicity of the compounds was evaluated in a non-tumor cell line (Vero), and they did not show relevant toxicity at their $\mathrm{GI}_{50}$ concentrations (presenting high $\mathrm{GI}_{50}$ values). Effects on the cell cycle profile and induction of apoptosis were evaluated for compounds $\mathbf{2 b}, \mathbf{2 f}$, and $\mathbf{2 g}$ in the AGS cell line. Nevertheless, even for the most active compound against this cell line $\left(\mathrm{GI}_{50}=7.8 \mu \mathrm{M}\right)$, it was observed that a huge number of dead cells gave rise to an atypical distribution on the cell cycle profile and that these cells were not apoptotic, which indicates that a different mechanism of action for the AGS cell growth inhibition is involved.

Supplementary Materials: The following are available online, ${ }^{1} \mathrm{H},{ }^{13} \mathrm{C}$, and ${ }^{19} \mathrm{~F}$ NMR spectra of the novel compounds $\mathbf{1 b}$ and $\mathbf{2 a - 2 o}$ are presented.

Author Contributions: Conceptualization, M.-J.R.P.Q., L.B. and I.C.F.R.F.; methodology, J.M.R., R.C.C. and A.N.; validation, J.M.R., R.C.C. and A.N.; formal analysis, J.M.R., R.C.C., A.N., L.B. and M.-J.R.P.Q.; resources, I.C.F.R.F., L.B. and M.-J.R.P.Q.; writing—original draft preparation, J.M.R., R.C.C., A.N. and M.-J.R.P.Q.; writing-review and editing, J.M.R., R.C.C., A.N., L.B. and M.-J.R.P.Q.; supervision, M.-J.R.P.Q.; project administration, L.B., I.C.F.R.F. and M.-J.R.P.Q.; funding acquisition, L.B., I.C.F.R.F. and M.-J.R.P.Q. All authors have read and agreed to the published version of the manuscript.

Funding: This research was funded by Fundação para a Ciência e Tecnologia (FCT)—Portugal, which financially supports CQUM (UID/QUI/686/2019), and also financed by the European Regional Develop- ment Fund (ERDF), COMPETE2020 and Portugal2020, and the PTNMR network also supported by Portugal2020. J.M.R. PhD grant (SFRH/BD/115844/2016) was financed by FCT, ESF (European Social Fund-North Portugal Regional Operational Program) and HCOP (Human Capital Operational Program). The authors are grateful to FCT, Portugal, for financial support through national funds FCT/MCTES to the CIMO (UIDB/00690/2020). L.B. and R.C.C. thank the national funding by FCT, Portugal, through the institutional scientific employment program-contract for their contracts.

Institutional Review Board Statement: Not applicable.

Informed Consent Statement: Not applicable.

Data Availability Statement: The data presented in this study are available in article and in the Supplementary Materials.

Conflicts of Interest: The authors declare no conflict of interest.

Sample Availability: Not available.

\section{References}

1. Hartwig, J.F. Transition Metal Catalyzed Synthesis of Arylamines and Aryl Ethers from Aryl Halides and Triflates: Scope and Mechanism. Angew. Chem. Int. Ed. 1998, 37, 2046-2067. [CrossRef]

2. Wolfe, J.P.; Wagaw, S.; Marcoux, J.-F.; Buchwald, S.L. Rational Development of Practical Catalysts for Aromatic Carbon-Nitrogen Bond Formation. Acc. Chem. Res. 1998, 31, 805-818. [CrossRef]

3. Yang, B.H.; Buchwald, S.L. Palladium-catalyzed amination of aryl halides and sulfonates. J. Organomet. Chem. 1999, 576, 125-146. [CrossRef] 
4. Schlummer, B.; Scholz, U. Palladium-Catalyzed C-N and C-O Coupling-A Practical Guide from an Industrial Vantage Point. Adv. Synth. Catal. 2004, 346, 1599-1626. [CrossRef]

5. Buchwald, S.L.; Mauger, C.; Mignani, G.; Scholz, U. Industrial-Scale Palladium-Catalyzed Coupling of Aryl Halides and Amines-A Personal Account. Adv. Synth. Catal. 2006, 348, 23-39. [CrossRef]

6. Corbet, J.-P.; Mignani, G. Selected Patented Cross-Coupling Reaction Technologies. Chem. Rev. 2006, 106, 2651-2710. [CrossRef]

7. Torborg, C.; Beller, M. Recent Applications of Palladium-Catalyzed Coupling Reactions in the Pharmaceutical, Agrochemical, and Fine Chemical Industries. Adv. Synth. Catal. 2009, 351, 3027-3043. [CrossRef]

8. Surry, D.S.; Buchwald, S.L. Dialkylbiaryl phosphines in Pd-catalyzed amination: A user's guide. Chem. Sci. 2011, 2, 27-50. [CrossRef]

9. Lundgren, R.J.; Stradiotto, M. Addressing Challenges in Palladium-Catalyzed Cross-Coupling Reactions Through Ligand Design. Chem. Eur. J. 2012, 18, 9758-9769. [CrossRef] [PubMed]

10. Ruiz-Castillo, P.; Buchwald, S.L. Applications of Palladium-Catalyzed C-N Cross-Coupling Reactions. Chem. Rev. 2016, 116, 12564-12649. [CrossRef]

11. Heravi, M.M.; Kheilkordi, Z.; Zadsirjan, V.; Haydari, M.; Malmir, M. Buchwald-Hartwig reaction: An overview. J. Organomet. Chem. 2018, 861, 17-104. [CrossRef]

12. Dorel, R.; Grugel, C.P.; Haydl, A.M. The Buchwald-Hartwig Amination After 25 Years. Angew. Chem. Int. Ed. 2019, 58, 17118-17129. [CrossRef] [PubMed]

13. Buskes, M.J.; Blanco, M.-J. Impact of Cross-Coupling Reactions in Drug Discovery and Development. Molecules 2020, $25,3493$. [CrossRef]

14. Taylor, E.C.; Reiter, A. Studies on the molybdenum cofactor. An unequivocal total synthesis of (.+-.)-urothione. J. Am. Chem. Soc. 1989, 111, 285-291. [CrossRef]

15. Lim, J.; Altman, M.D.; Gibeau, C.R. Thienopyrazine Inhibitors of IRAK4 Activity. WO Patent 2016144849, 15 September 2016.

16. Guerin, D.J.; Bair, K.W.; Caravella, J.A.; Ioannidis, S.; Lancia, D.R., Jr.; Li, H.; Mischke, S.; Ng, P.Y.; Richard, D.; Sciller, S.E.R.; et al. Thienopyrazine Carboxamides as Ubiquitin-Specific Proteases Inhibitors. WO Patent 2017139779, 17 August 2017.

17. Folmer, B.J.B.; de Man, A.P.A.; Gernette, E.S.; Azevedo, R.C.R.G.; Ibrahim, H. Thieno[2,3-b]pyrazine Compounds as B-Raf Inhibitors. WO Patent 2011147764, 1 December 2011.

18. Queiroz, M.-J.R.P.; Calhelha, R.C.; Vale-Silva, L.A.; Pinto, E.; Nascimento, M.S.-J. Novel 6-[(hetero)arylamino]thieno[3,2b]pyridines: Synthesis and antitumoral activities. Eur. J. Med. Chem. 2010, 45, 5732-5738. [CrossRef]

19. Queiroz, M.-J.R.P.; Peixoto, D.; Calhelha, R.C.; Soares, P.; dos Santos, T.; Lima, R.T.; Campos, J.F.; Abreu, R.M.V.; Ferreira, I.C.F.R.; Vasconcelos, M.H. New di(hetero)arylethers and di(hetero)arylamines in the thieno[3,2-b]pyridine series: Synthesis, growth inhibitory activity on human tumor cell lines and non-tumor cells, effects on cell cycle and on programmed cell death. Eur. J. Med. Chem. 2013, 69, 855-862. [CrossRef]

20. Calhelha, R.C.; Ferreira, I.C.F.R.; Peixoto, D.; Abreu, R.M.V.; Vale-Silva, L.A.; Pinto, E.; Lima, R.T.; Alvelos, M.I.; Vasconcelos, M.H.; Queiroz, M.-J.R.P. Aminodi(hetero)arylamines in the Thieno[3,2-b]pyridine Series: Synthesis, Effects in Human Tumor Cells Growth, Cell Cycle Analysis, Apoptosis and Evaluation of Toxicity Using Non-Tumor Cells. Molecules 2012, 17, 3834-3843. [CrossRef]

21. Blanco, G.; Quintela, J.M.; Peinador, C. Application of the aza-Wittig reaction to the synthesis of pyrazinothienotriazolopyrimidinones: A new tetracyclic ring system. Tetrahedron 2008, 64, 1333-1344. [CrossRef]

22. Rodrigues, J.M.; Buisson, P.; Pereira, J.M.; Pinheiro, I.M.; Fernández-Marcelo, T.; Vasconcelos, M.H.; Berteina-Raboin, S.; Queiroz, M.-J.R.P. Synthesis of novel 8-(het)aryl-6H-pyrano[ $\left[4^{\prime}, 3^{\prime}: 4,5\right]$ thieno[3,2-b] pyridines by 6-endo-dig cyclization of Sonogashira products and halolactonizations with Cu salts/NXS. Preliminary antitumor evaluation. Tetrahedron 2019, 75, 1387-1397. [CrossRef]

23. Yin, J.; Zhao, M.M.; Huffman, M.A.; McNamara, J.M. Pd-Catalyzed N-Arylation of Heteroarylamines. Org. Lett. 2002, 4, 3481-3484. [CrossRef] [PubMed]

24. Teixeira, A.; Da Cunha, D.C.; Barros, L.; Caires, H.R.; Xavier, C.P.R.; Ferreira, I.C.F.R.; Vasconcelos, M.H. Eucalyptus globulus Labill. decoction extract inhibits the growth of NCI-H460 cells by increasing the p53 levels and altering the cell cycle profile. Food Funct. 2019, 10, 3188-3197. [CrossRef] [PubMed]

25. Long, S.; Resende, D.; Kijjoa, A.; Silva, A.M.S.; Pina, A.; Fernandez-Marcelo, T.; Vasconcelos, M.H.; Sousa, E.; Pinto, M.M.M. Antitumor activity of quinazolinone alkaloids inspired by marine natural products. Mar. Drugs 2018, 16, 261. [CrossRef] [PubMed]

26. Phang, C.-P.; Karsani, S.A.; Sethi, G.; Malek, S.N.A. Flavokawain C Inhibits Cell Cycle and Promotes Apoptosis, Associated with Endoplasmic Reticulum Stress and Regulation of MAPKs and Akt Signaling Pathways in HCT 116 Human Colon Carcinoma Cells. PLoS ONE 2016, 11, e0148775. [CrossRef] [PubMed]

27. Esmaeelian, B.; Benkendorff, K.; Johnston, M.R.; Abbott, C.A. Purified Brominated Indole Derivatives from Dicathais orbita Induce Apoptosis and Cell Cycle Arrest in Colorectal Cancer Cell Lines. Mar. Drugs 2013, 11, 3802-3822. [CrossRef] [PubMed] 